\title{
Antibody-based therapeutic interventions: possible strategy to counter chikungunya viral infection
}

\author{
Rajesh Kumar $^{1} \cdot$ Tripti Shrivastava $^{1} \cdot$ Sweety Samal ${ }^{1} \cdot$ Shubbir Ahmed $^{1} \cdot$ Hilal Ahmad Parray ${ }^{1}$
}

Received: 16 October 2019 / Revised: 29 January 2020 / Accepted: 5 February 2020 / Published online: 19 February 2020

(C) Springer-Verlag GmbH Germany, part of Springer Nature 2020

\begin{abstract}
Chikungunya virus (CHIKV), a mosquito-transmitted disease that belongs to the genus Alphaviruses, has been emerged as an epidemic threat over the last two decades, and the recent co-emergence of this virus along with other circulating arboviruses and comorbidities has influenced atypical mortality rate up to $10 \%$. Genetic variation in the virus has resulted in its adaptability towards the new vector Aedes albopictus other than Aedes aegypti, which has widen the horizon of distribution towards nontropical and non-endemic areas. As of now, no licensed vaccines or therapies are available against CHIKV; the treatment regimens for CHIKV are mostly symptomatic, based on the clinical manifestations. Development of small molecule drugs and neutralizing antibodies are potential alternatives of worth investigating until an efficient or safe vaccine is approved. Neutralizing antibodies play an important role in antiviral immunity, and their presence is a hallmark of viral infection. In this review, we describe prospects for effective vaccines and highlight importance of neutralizing antibody-based therapeutic and prophylactic applications to combat CHIKV infections. We further discuss about the progress made towards CHIKV therapeutic interventions as well as challenges and limitation associated with the vaccine development. Furthermore this review describes the lesson learned from chikungunya natural infection, which could help in better understanding for future development of antibody-based therapeutic measures.
\end{abstract}

Keywords Therapeutics $\cdot$ Neutralizing antibodies $\cdot$ Vaccines $\cdot$ Viral pathogen $\cdot$ Prophylactics

\section{Introduction}

Chikungunya disease has emerged as an epidemic threat over the past 2 decades, causing serious global health problem. The disease has significant socioeconomic impact, severely affecting the health care system due to difficulty in diagnosis, lack of proper treatment protocol and delay in the treatment processes. CHIKV infection is reported all around the world, and, in the USA, it has been listed as Priority Pathogen (as a Category B) by National Institute of Allergy and Infectious Diseases (NIAID) (https://www.niaid.nih.gov/research/ emerging-infectious-diseases-pathogens). Category B pathogens are the second highest priority biological agents, which moderately disseminate with low mortality rate

Rajesh Kumar

rajesh@thsti.res.in

1 Translational Health Science \& Technology Institute, NCR Biotech Science Cluster, Faridabad, Haryana 121001, India
(Bhooshan et al. 2015; Dinkar et al. 2018). The economic burden of disease varies between different epidemics and also depends on physical status and financial access to health care facility. The 2006 epidemic report of India suggests that over $72 \%$ of patients were suffered from arthralgia (Vijayakumar et al. 2011; Weaver et al. 2012). However, the disability-adjusted life years (DALYs) lost was estimated to be 25,588 , with an overall burden of 45.26 DALYs per million arthralgia (Krishnamoorthy et al. 2009; Weaver et al. 2012).

Chikungunya is a viral disease transmitted to humans by infected Aedes species mosquitoes and is characterized by fever, rashes and severe joint pain. Other symptoms include muscle pain, myalgia, headache, nausea, fatigue and rash (Simon et al. 2015). The name 'Chikungunya' is derived from Kimakonde language of Mozambique which means 'to walk bent over'. The disease caused by CHIKV is an arbovirus (arthropod borne virus) and belongs to genus alphavirus of Togaviridae family. It was first reported in 1952 in Tanzania outbreak and was isolated in 1953 from patient serum and mosquitoes (Robinson 1955; Suhrbier et al. 2012). 
The alphaviruses genus comprise of 31 viruses, which are commonly referred to as 'New World' and 'Old World' viruses. 'New World' viruses are primarily associated with potentially fatal encephalitic disease, while the 'Old World' viruses are responsible for acute febrile illnesses followed by severe polyarthralgia (Runowska et al. 2018). Out of 31 alphavirus, 7 are associated with human joint disorder like symptoms, namely, CHIKV, Ross River (RRV), Barmah Forest (BFV) (Australia and the Pacific), Semliki Forest (SFV), O'NyongNyong (ONNV) (Central Africa), Sindbis (cosmopolitan) and Mayaro (MAYV) (South America and French Guyana) viruses and are categorized as old world virus (Petitdemange et al. 2015; Suhrbier et al. 2012). Recent epidemic and reemergence of the CHIK viral disease in non-endemic areas of global territories have brought waves of higher incidences of morbidity and fatality (Freitas et al. 2018; Mavalankar et al. 2008). The precise causative factors associated with CHIKV emergence/re-emergence are still not clearly defined, but it has been hypothesized that, in addition to ecologic and viral factors, the immune status of the affected populations in a particular geographical location also plays an important role in higher intensity and periodicity of recurrence (Petitdemange et al. 2015).

Currently, there are no approved vaccines or antiviral drugs available for the prevention or treatment of CHIKV. Due to lack of licensed vaccines, therapies or effective antivirals against CHIKV, the treatment regimens are mostly symptomatic and are based on the clinical manifestations (Fig. 1). The most common approach used in the preventive measures includes strategies to prevent spread of mosquitoes by using insect repellents, the elimination of standing water where mosquitoes could lay eggs, the minimization of skin surface exposed to mosquito bites and the installation of window and door screens.

Although, antibody therapy has been shown as a promising approach in the prevention or treatment of CHIKV disease in preclinical animal models. The major challenges for implementing such therapies in human treatment are still in progress (Burt et al. 2017). Antibody-based therapeutics is of particular interest in the context of emerging disease outbreaks (Marston et al. 2018). In disease outbreaks, the process of vaccine development for new pathogens or re-emerged strains may be difficult and a prolonged process. In this review, we described the substantial advancement made in isolation of CHIKV monoclonal antibodies (mAbs) and potential implication as a therapeutic or prophylactic agent, in vitro and in vivo experiments of $\mathrm{mAbs}$ in various models and role of antibodies in modulating CHIKV infection. We highlighted the role of the natural humoral system in controlling chikungunya infection and the lesson learned from the natural infection that helps in a better understanding of future expectancy for the development of antibody-based therapeutic measures. We also discussed the importance and challenges associated with vaccine development and antibody-based therapeutics for chikungunya.

\section{Chikungunya pathogenesis (symptoms and life cycle)}

CHIKV infection is generally self-limiting and acute symptoms resolve within 1 to 2 weeks. About $80-85 \%$ of infected individuals develop symptoms out of which $90-95 \%$ of infected individuals develop acute debilitating polyarthralgia (Sa et al. 2017) with rare reports of fatality (1 in 1000) (Josseran et al. 2006). However, the recent re-emergence and its co-infection with other related viruses have shown atypical mortality rate up to $10 \%$ over the past few years (Economopoulou et al. 2009). The presence of other comorbidities influences the mortality rate of CHIKV infection (Chow et al. 2011; Economopoulou et al. 2009). The major challenge is to differentiate clinical signs of alphaviruses like dengue, CHIKV and ZIKA, especially when these viruses are in co-circulation. Both dengue and CHIKV are transmitted by the same Aedes vector, and thus both infections belong to the same ecological niche and are epidemiologically and spatially related. In dengue-endemic area, CHIKV is mainly misdiagnosed or under-diagnosed as acute CHIKV infection is usually associated with dengue-like symptoms, except CHIKV infection is associated with intense arthralgia. The clinical manifestations like polyarthralgia, myalgia/arthralgia of greater severity are strong predictive symptoms for chikungunya; such long-lasting symptoms are typically not observed in dengue fever (Chow et al. 2011; Fric et al. 2013).

The elderly patients, pregnant women, neonates and individuals with other health problems like hypertension, respiratory conditions and diabetes mellitus are at higher risk for severe CHIKV disease (Tharmarajah et al. 2017). The most common manifestations that occur in these cases are due to neurological and non-neurological manifestations like abnormal cellularity with elevated protein levels in the CSF (Burt et al. 2017; Marston et al. 2018; Tharmarajah et al. 2017). The children born from women infected with CHIKV during the first two trimesters of pregnancy have more than $50 \%$ chances of developing abnormalities including preterm birth, cardiac defects and hyperpigmentation (Barr and Vaidhyanathan 2019; Senanayake et al. 2009). The higher frequency of patients having neurological manifestations is more reported recently in the elderly in CHIKV-infected cases with other comorbidities. These data suggest that the virus can manipulate and evade the immune system to reach the brain and its surrounding structures resulting in ineffective immune responses, which subsequently fail to control viral spread and high viremia. Women are also found to be more vulnerable and can be grouped under increased risk group for CHIKV infection (Runowska et al. 2018; Senanayake et al. 2009). 
CHIKV infection is mainly divided into three phases: acute (the first 3 weeks from the onset of clinical symptoms), postacute (from 21st day to the end of 3rd month) and chronic stage (after 3 months from onset of clinical symptoms). The incubation period for CHIKV is between 2 and 4 days. CHIKV infection triggers a rapid innate immune response by strong activation of type 1 interferon (IFN) and proinflammatory cytokines (Tang 2012). The CHIKV infection is characterized by a high viral load ranging from $10^{5}$ up to $10^{12}$ viruses per milliliter of blood (Hoarau et al. 2010) (Fig. 2). High viral load is more likely to be detected in new-born (Tanabe et al. 2018) and elderly patients that contribute to disease severity in these age groups. Approximately two-thirds of infected individuals (30 to 60\%) with CHIKV develop persistent arthritis that lasts for months to years after the initial onset of infection. The severity of disease also depends on viral and host factors. It is reported that some of the lineage viruses replicate to a higher level as compared with other lineage viruses, and these differences can be correlated in terms of acute-phase disease severity as well as associated prolonged symptoms (Jin et al. 2015; Kam et al. 2012c; Pal et al. 2013). Unlike other mosquito-borne viruses such as dengue (DENV) and West Nile virus (WNV), the majority of individuals exposed to CHIKV become symptomatic (Kam et al. 2012c). Debilitating polyarthralgia is reported in majority of symptomatic patients; however, children tend to display milder arthralgia (Gardner et al. 2010; Kam et al. 2012c). Encephalitis appears to be the most common clinical manifestation in neurological complications in CHIKV infection. It develops within a few days of onset of systemic symptoms, during the period of viremia (Chandak et al. 2009; Kashyap et al. 2010). Recent reports have suggested that persons having a previous history of dengue virus infection or arbovirus have more chances of having atypical severe CHIKV infection with dermatological diseases. However, the mechanism that contributes to persistent arthritis is unclear and is not well understood. A recent study showed that the virus uses the molecular mimicry mechanism to escape and evade host immune responses (Lin et al. 2011; Reddy et al. 2017). Two peptides from CHIKV envelope glycoprotein are showing homology and similarity with the host proteins. This molecular mimicry between CHIKV E1 glycoprotein and host human
Fig. 1 Infographic showing different symptoms of CHIKV infection and methods of prevention: a, b Common CHIKV infection symptoms icons include fever, headache, depression, tiredness, nausea, acute or chronic joint pains and rash. c Interventions like vaccine, antiviral drugs or monoclonal antibody therapy could be beneficial for prevention and treatment of CHIV infection

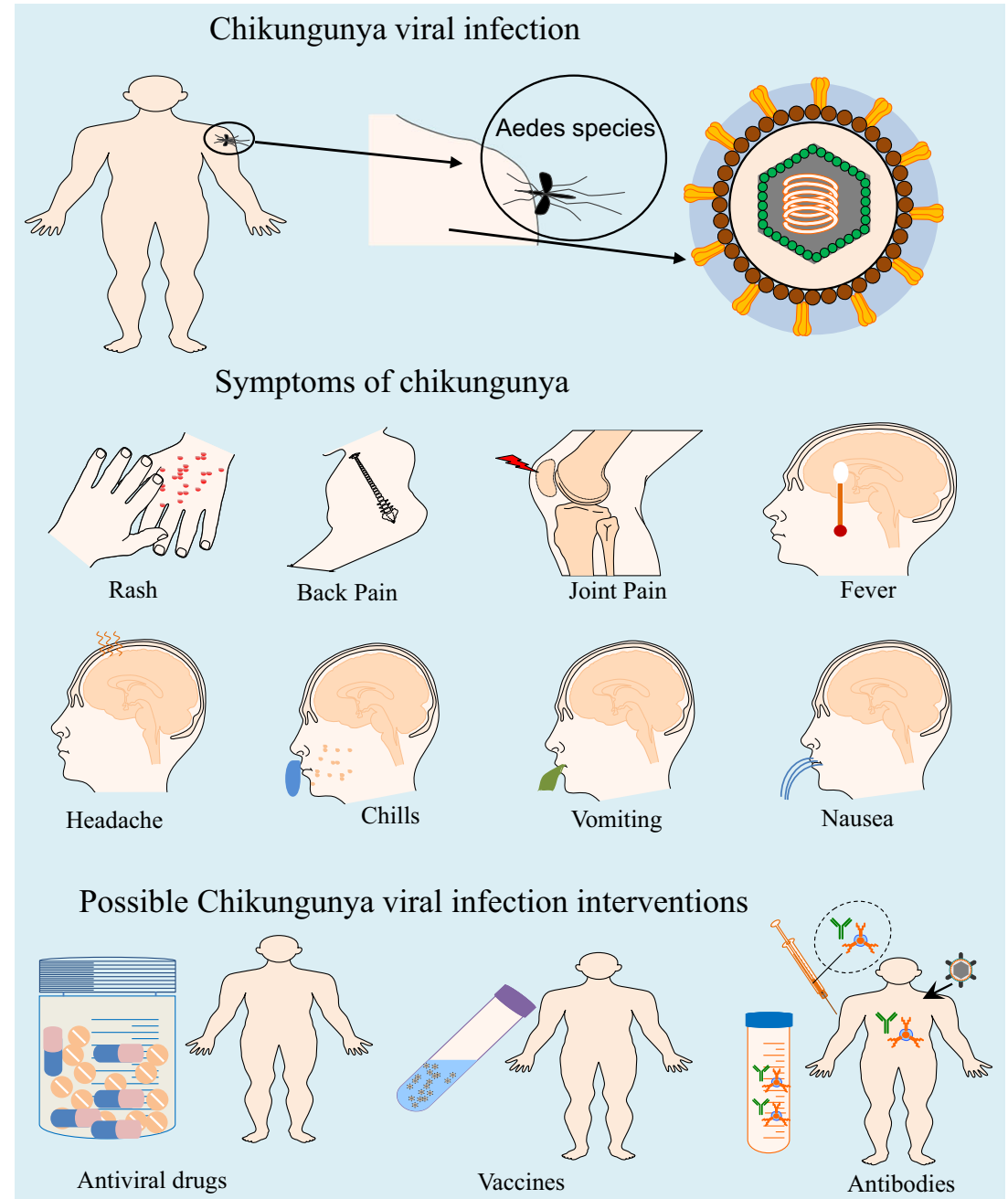


components might be responsible for debilitating polyarthralgia in CHIKV infected patients (Reddy et al. 2017). In some reports, CHIK viral RNA/antigen has been detected in joint-associated tissue and lymphoid tissue even after several months of acute infection (Cardona-Correa et al. 2017; Kam et al. 2012c). Moreover, there are no reports till date that suggests the presence of actively replicating virus during the chronic phase. It is assumed that viruses may 'hijack' and replicate in synovial macrophages, as CHIKV viralRNA (vRNA) may drive an aberrant inflammatory response resulting in chronic infection in human tissues (Hoarau et al. 2010). It has been shown that, in acute phase, CHIKV infects a wide range of host cells such as fibroblasts, synoviocytes, macrophages, skeletal muscle fibers, satellite cells, osteoblasts, endothelial cells, keratinocytes and neuronal cells (Cardona-Correa et al. 2017; Miner et al. 2017). However, cells that harbor the CHIKV RNA during the chronic phase are unknown, possibly due to the low sensitivity of detection techniques. To identify the cells that might contribute to pathogenesis during this chronic phase, Young et al. (2019) developed a novel recombinant CHIKV system that expresses Cre recombinase (CHIKV-3'-Cre). This model system can be a useful tool for understanding CHIKV pathogenesis in the acute and chronic disease stages and will help in the future development of intervention strategies (Freitas et al. 2018).

\section{CHIK virus and infectious cycle}

CHIKV is a small enveloped virus (70 $\mathrm{nm}$ virions) with a positive-strand RNA genome of $12 \mathrm{~kb}$ long in size and consists of two open reading frames (ORF). ORF one encodes for non-structural proteins that are responsible for replication of the virus in the host cell cytoplasm, and second ORF encodes the structural proteins: capsid and envelope. The virus particle is formed of approximately 240 copies of capsid protein, embedded in approximately 80 spikes of envelope trimers of E1 and E2 glycoprotein heterodimers. The virus is believed to be originated from Africa and then spread to Asian countries (Burt et al. 2017). In 2004, CHIKV re-emerged and spreads its tertiary towards non-tropical countries. In 2005 and 2006, CHIKV outbreak was reported in India and La Re'union, causing a severe health concerns. About one third (34\%) of the population in Reunion Island (Charrel et al. 2007) and over 1.3 million people in India were infected with virus (Krishnamoorthy et al. 2009). In 2007, the virus first time emerged in Italy (Rezza 2018). A genetic variation in the virus envelope protein has resulted in the virus adaptability towards new vector Aedes albopictus (than Aedes aegypti), which has widened the horizon of distribution towards non-tropical and previous non-endemic areas to temperate regions (Burt et al. 2017). This adaptability to the new vector has increased the infectivity of virus, causing efficient replication and dissemination to the vertebrate host by Aedes albopictus (Tsetsarkin et al. 2007).

CHIKV virus is transmitted both horizontally and vertically; horizontal transmission occurs during mosquito bites to a viremic patient (or previously infected patients with viral load). The viruses are transmitted through a blood meal, replicates in mosquito midgut and migrate to the salivary glands from where virus disseminates to next host during bite/blood meal. The mechanism of vertical transmission ensures CHIKV adaptability to survive under adverse condition (Wong et al. 2016). Virus replicates in the ovaries of the carrier mosquitoes and the virus harboring eggs ensure the potential viral survival by protecting the virus from adverse
Fig. 2 Following transmission through mosquito's bites, virus replicates in the skin and fibroblasts cells, enters the bloodstream and disseminates to other tissue organs like liver, muscle, joints and lymphoid tissues. After an incubation period of 2 to 7 days, an abrupt onset of symptoms including high fever, muscle pain, skin rash, weakness and headache. Symptoms remain for about 4-8 days as a selflimiting disease. Neutralizing IgM responses appear as early as days 2-4 of onset of symptoms. As soon as the level of IgM antibodies increases from day 4 to 10 , the viral load decreases. After a point (after day 10), IgM acts in a complementary manner with the early $\mathrm{IgG}$ antibodies
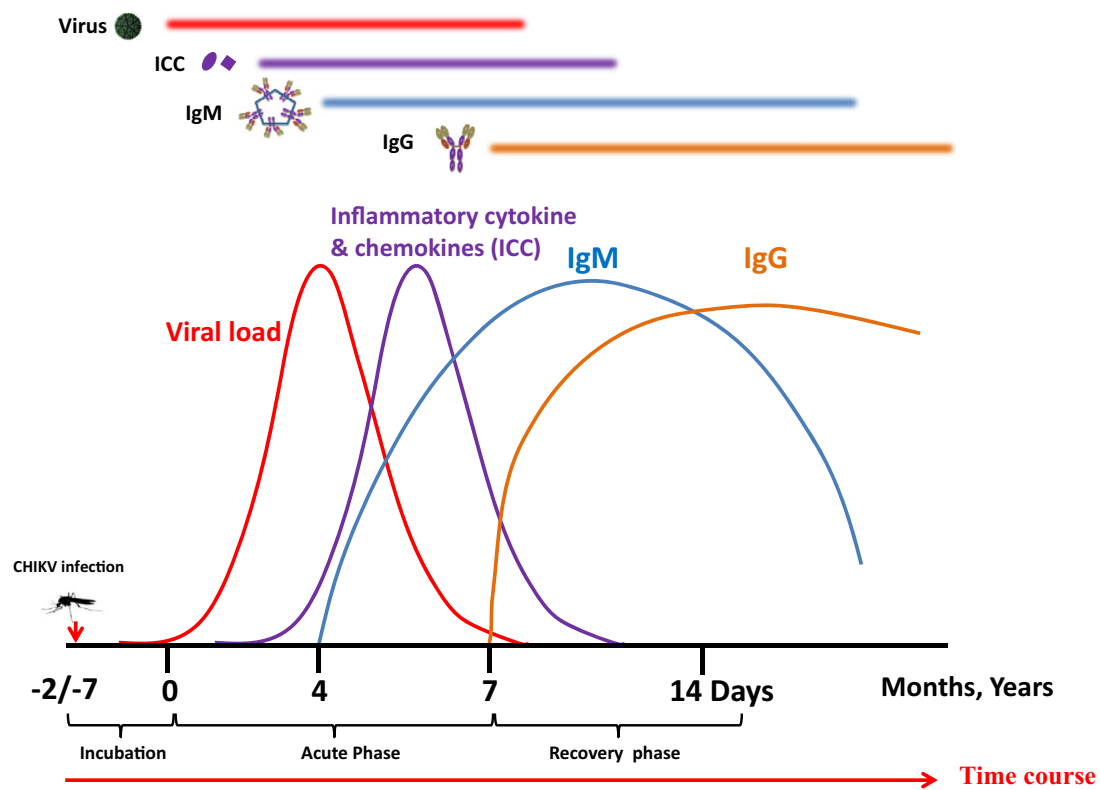
environmental conditions hence survival of the virus (Hardy et al. 1983; Matusali et al. 2019; Rosen et al. 1983). Besides, the virus can also transmit directly from one individual to another through needle stick injury, organ graft, blood donations and from infected mother to the neonates (Couderc et al. 2012; Parola et al. 2006; Rosso et al. 2018). In a recent study, CHIKV has also been detected in the breast milk of CHIKV infected mother; however, there is no report on the transmission of the virus from mother to the breast feeding baby. (Campos et al. 2017).

CHIKV infections could be endemic or epidemic or both. CHIKV is transmitted to the human population by mosquito bite, which maintained in a zoonotic cycle and involves both sylvatic and urban cycles. In the sylvatic transmission cycle, the virus is maintained between nonhuman primates, bats, rodents and other vertebrates; these animals develop viremia but no physical manifestations or symptoms (Erasmus et al. 2016; Petitdemange et al. 2015). Outbreaks in rural areas are mostly due to sylvatic cycle where mosquitoes are capable of infecting both primates and humans. However, primates act as the main virus reservoirs for sylvatic cycle. In Africa, CHIKV is primarily maintained in a sylvatic cycle (Powers and Logue 2007). Most of the endemic infections take place in rural areas in the form of small outbreaks or isolated population. In Asia, CHIKV typically circulates through urban cycle by peri-domestic A. aegypti and A. albopictus mosquitoes and the human hosts without the need for animal reservoirs. In urban cycle, the transmitted virus directly circulates in the human host through the human-mosquito-human transmission cycle because of the sufficiently high levels of viremia developed in the infected individuals (Go et al. 2014; Tan et al. 2011). The urban cycle can also start with the spillover of enzootic/sylvatic CHIKV via vectors (Diallo et al. 2012) (Fig. 3).

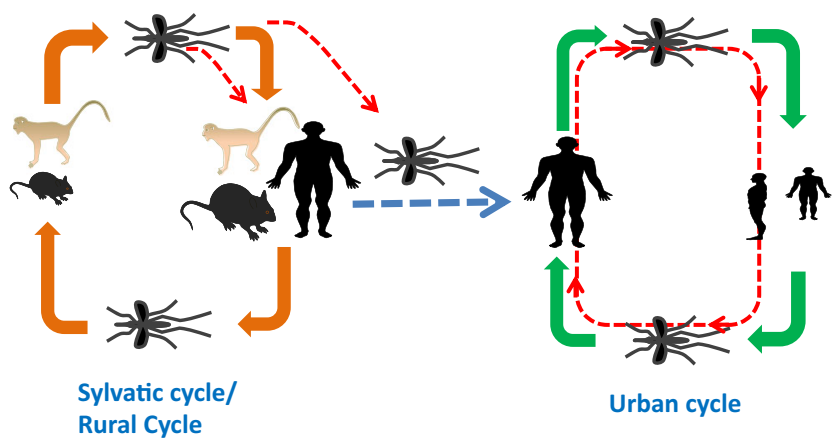

Fig. 3 Infographic showing transmission cycles of chikungunya virus (CHIKV). The virus is maintained in two cycles: sylvatic cycle that primarily occurs in Africa and virus is maintained between non-human primates, bats, rodents and other vertebrates. In urban cycle that primarily occurs in Asia where transmitted virus directly circulates in human host through human-mosquito-human transmission cycle

\section{Lesson learned from natural infection}

In this section, we have discussed how studies in past on chikungunya outbreaks could help in better understanding of the disease and host immune response thus enabling us for the development of antibodies with therapeutic potential.

\section{Immunoglobulin's in CHIKV infection: a lesson learned}

\section{Role of IgG}

Studies have shown that protection from CHIKV infection is mainly because of neutralizing antibodies. Studies conducted on human samples from CHIKV infected or recovered individuals had clearly shown that neutralizing $\operatorname{IgG}$ persists in these subjects for several months to years exhibiting lifelong immunity.

Initial neutralizing IgG immune response in these subjects are mostly targeted against linear epitopes, although in vivo animal immunization studies with linear epitope has shown mild neutralizing activity and partial protection (Kam et al. 2012b). The immunization studies with inactivated or attenuated whole virion CHIKV induce strong neutralizing IgG response and an effective in vivo protection (Goh et al. 2013; Plante et al. 2011). This suggests that strong $\mathrm{nAb}$ response is dependent on better representation of native trimeric envelopes as compared to the linear one (Jin and Simmons 2019). Studies conducted on patient samples have clearly demonstrated that CHIKV infection induces a robust humoral/B cell immune response. Most of the infected patients developing early neutralizing antibodies had less severe chronic symptoms. This neutralizing activity of anti-CHIKV $\mathrm{IgG}$ might be responsible for lifelong protection. Persistence and a high level of neutralizing antibodies have been detected even after 20 years of primary CHIKV infection. The presence of these high titers of neutralizing antibodies could be due to multiple exposures to the same or different lineage viruses that act as a booster in the natural course over years (Nitatpattana et al. 2014).

Among the different classes of IgGs response developed during CHIKV infection, IgG3 subtype is predominant. In CHIKV infection patients with high viral load rapidly develop high levels of anti-CHIKV IgG3 antibodies. These patients develop more severe acute symptoms, the virus is cleared faster and patients develop less persistent arthralgia. However, an inverse correlation was found in patients who develop late IgG3 with low viremia because, at this disease stage, virus is no longer detectable in the blood (Kam et al. 2012a), such patients have found to develop persistent arthralgia in later stages. In joint biopsies of patients with chronic arthralgia, virus has been detected in macrophages, while it is plausible that these viruses are in non-replicative stage 
(Hawman et al. 2013; Hoarau et al. 2010; Labadie et al. 2010). The high level of anti-CHIKV IgG3 response has also been shown to be associated with a higher level of cytokine production, which increases along with $\operatorname{IgG} 3$, apparently known as major B cell growth factor and inducer of IgG3 (Hirano et al. 1985; Kam et al. 2012c; Kawano et al. 1994). Induction of neutralizing antibodies in the early stage of acute infection is crucial to prevent persistent complications of chronic viral infections; therefore, the absence of early CHIKV-specific IgG3 antibodies might serve as a specific marker for patients with increased risk of disease (Kam et al. 2012b). As IgG3 is the dominant class of neutralizing antibodies in the early stage of CHIKV infection, it can readily transfer through the placenta in case of pregnant women and could protect newborns from CHIKV infection (Palmeira et al. 2012). Studies show that passive transfer of neutralizing antibodies to healthy pregnant women could also protect the newborn from subsequent infections (Englund 2007). It has been proven in several studies that these neutralizing IgGs or mAbs show the protective effect when given as pre-exposure prophylaxis in immune compromised animal models against lethal CHIKV challenge (animal model used in CHIKV studies are explained in detail in next session of this review). Post-exposure therapy of these IgGs or mAbs also reduces the severity of disease by limiting the viral spread to muscle and joint tissues.

\section{Role of IgM}

In the human immune system, $30 \%$ of circulating antibodies are IgM. The high percentage of these naturally circulating antibodies plays an important role in early recognition and elimination of external pathogens like bacteria and viruses before the development of robust and specific IgG secondary immune response (Vollmers and Brandlein 2005).

In CHIKV infections, early neutralization responses are due to IgM antibodies, which are followed by robust IgG response. Early IgM response in viral infection is important to confer protection, particularly in early stages of infection by enhancing antigen entrapment to the secondary lymphoid organs and bridging the innate and adaptive immunity before the IgG response. Viruses that infect mucosal surfaces encounter secretory IgA antibody responses first present at the apical surfaces of epithelial cells (Blutt and Conner 2013). However viruses that spread in the blood will be exposed to IgM first followed by $\operatorname{IgG}$ antibodies.

Neutralizing IgM responses first appear as early as days 2 4 of onset of symptoms, and their appearance from day 6 is associated with a reduction in viral load (Petitdemange et al. 2015). IgM has the dominant neutralizing role up to 8-10 days from the onset of clinical symptoms, followed by variable but strong contributions by neutralizing $\mathrm{IgG}$. In some cases, it has been reported that IgM even persists from several weeks to a year after resolution as shown in Fig. 2. The persistence of
IgM antibodies for months after the initial infection has been reported in other alphavirus infections also, and this is believed to be due to viral persistence, though the exact mechanism is not well characterized. However, one possible mechanism for persistence of long-lasting IgM response could be due to viral evade T cell-dependent IgG and IgA responses by attenuating CD40L gene expression. Such an evasion mechanism has been postulated previously with various other viral infections (Lin et al. 2005; Malvy et al. 2009; Qiao et al. 2006; Sitati et al. 2007). The presence of anti-CHIKV IgM antibodies has also been detected in the cerebrospinal fluid of human neonates and patients with encephalopathy (Couderc et al. 2009; Dunman and Nesin 2003). Patients with chronic CHIKV-induced arthralgia have often been correlated with persistent virus-specific IgM antibodies, which could be due to continued exposure to CHIKV antigen and RNA (Couderc and Lecuit 2015; Hoarau et al. 2010; Levade et al. 1991; Malvy et al. 2009). The long term survival and persistence of CHIKV have also been reported in non-human primate by evading immune defense mechanisms (Labadie et al. 2010).

As soon as the level of IgM antibodies increases from day 4 to 10 the viral load decreases. After a point (after day 10), IgM acts in a complementary manner with the early IgG antibodies. The IgM antibodies preferentially bind to epitopes on the native E1-E2 fusion glycoprotein of the CHIK viral surface (Tanabe et al. 2018). A neutralizing monoclonal IgM antibody isolated from mice has shown to target N218 of domain B of E2 protein with increased breadth and potency. This $\mathrm{mAb}$ has shown to block the virus attachment in the permissive host cells (Lam et al. 2015).

The amount and timing of the appearance of neutralizing antibodies (both IgM \& IgG) have a major significant impact on CHIKV clinical outcomes. This neutralizing IgM response varies within individuals. Surveillance studies have shown the persistence of IgM antibodies in serum of CHIKV infected patients for 11-18 months post-infection. The percentage of IgM positive patients in different surveillance studies varies from 11 to 55\% of sample populations (Chua et al. 2017; Pierro et al. 2015).

The pentameric nature of IgM antibodies makes them efficiently mediate virus aggregation, recognition and destruction by cytotoxic T cells. The short half life span of IgM antibodies can render their neutralizing effectiveness, but the indirect function of IgM antibodies makes them attractive agents to inhibit viral budding and clearance of infected cells by activating the complement- mediated pathways (Landry 2016).

\section{Present and future of therapeutic options}

Humoral immunity holds the center stage for protection against CHIKV infection. Several vaccine candidates for CHIKV are under development including attenuated or 
inactivated, chimeric, subunit and genetic vaccines (Powers 2018), which are focus of eliciting long-term humoral responses. The clinical studies conducted on these different vaccine candidates highlights the importance of humoral immunity in controlling CHIKV infection. However, challenges associated with chikungunya vaccine development has been discussed in detail in the next section.

Monoclonal antibody $(\mathrm{mAb})$-based therapeutics are alternative ways of treatment when effective vaccines are not available or do not confer protection (Pelfrene et al. 2018). The increasing emergence of resistant/escape variants of the various pathogens has opened the door for $\mathrm{mAb}$-based therapeutics (Berkelman et al. 1994; Lim et al. 2014). Antibodybased therapeutics has several advantages over vaccineinduced immunity, provides quick protection, is safe in highrisk population (immunocompromised hosts, pregnant women, elderly patients etc.) and can be made available faster than vaccines during emergencies and outbreaks (Sparrow et al. 2017). The rapid and strategic development of highly specific antibody-based preventive and therapeutic interventions has the potential to transform the course of an epidemic loss (Mavalankar et al. 2008). Passive administration of antibodies has the potential for a near-immediate onset of action, compared with vaccines that require weeks to months to induce protective immune effects (Freitas et al. 2018). Further, mAbs can work via different mechanisms i.e. by direct neutralization of target antigen and also by indirect effector mechanisms such as antibody-dependent cell-mediated cytotoxicity (ADCC), complement-dependent cytotoxicity (CDC) and phagocytosis, wherein, mAbs bind to infected cells and potentially clear the reservoirs (Hey 2015) (Fig. 4).

Antibody-based therapeutics has better success expectancy in viral diseases like CHIK where the virus is less divergent. CHIKV constitutes of a single serotype with four different genetic lineages or genotypes, West African, East/Central/ South African (ECSA) and Asian and Indian Ocean lineage (IOL) (Volk et al. 2010). These different lineages are classified based on the sequence of the E1 gene (Erasmus et al. 2016; Volk et al. 2010). CHIKV is a highly conserved virus as compared with the other highly variable viruses like HIV, influenza and hepatitis. The envelope sequences of different CHIKV lineages are 95-99.9\% conserved (Erasmus et al. 2016), and this genetic-conserved nature of the envelope makes it an attractive target for neutralizing antibodies. NAbs isolated against one lineage virus might be highly effective for other lineage viruses. Neutralizing antibodies in chikungunya viral infection mainly targets two sites. The first site is receptor binding site on the viral envelope where nAbs bind to and blocks the viral fusion to the host cell membrane and another site is to prevent post-receptor binding conformational changes (Jin and Simmons 2019).

The CHIKV binds to the host cell via its envelope glycoprotein and enters via receptor-mediated endocytosis followed by $\mathrm{pH}$-mediated fusion with the host cell membrane. The envelope glycoprotein is a trimer of heterodimers of E1 and E2 (Akahata et al. 2010). Both E1 and E2 participate complementarily in CHIKV cell entry. The E2 is mainly responsible for cell attachment, and E1 helps in fusion and promotes viral membrane fusion within acidified endosomes to release CHIKV nucleocapsid into the host cell cytosol. The E2 glycoprotein is found to be the major target of neutralizing antibodies in naturally acquired immunity in CHIKV infected patients with cleared viremia (Kam et al. 2012b). The mature E2 protein forms 3 immunoglobulin-like fold structure and is made up of three domains: domain $\mathrm{A}$ at the $\mathrm{N}$ terminus located in the center of the protein, domain $\mathrm{C}$ at the $\mathrm{C}$ terminus spotted close to the viral membrane and domain $\mathrm{B}$ at the tip prominently exposed on the viral surface. These domains are principle sites on CHIK viral surface for interaction with host target cells. These three domains are interconnected by betaribbon. Recent studies have shown that CHIKV enters into the host cells through two different mechanisms i.e. one by glycosaminoglycans (GAGs) dependent via domain B and other GAG-independent mechanism via domain A. These studies give us a clue that domain $\mathrm{B}$ and $\mathrm{A}$ could be a promising target for developing neutralizing antibody-based therapeutics (Weber et al. 2017). Several monoclonal antibodies targeting E2 domain have been isolated, and their therapeutic efficiencies have been tested in different animal modes. A detailed description of these mAbs has been discussed in review (Jin and Simmons 2019) and Table 1. Based on alanine scanning mutagenesis and escape mutation studies, the important residues on domain A and domain B of E2 subunit are identified

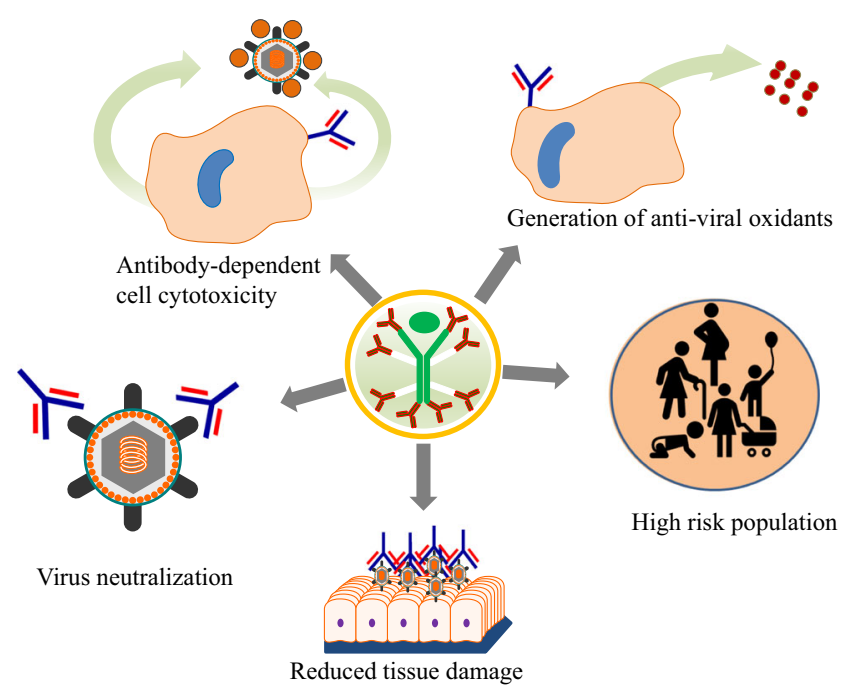

Fig. 4 Summary of immune regulatory mechanisms of monoclonal antibody: the Y-shaped represent the antibody. The antibody can neutralize the virus envelope proteins; generate antioxidants that can clear viruses; generate immune regulation beneficial for high-risk population like pregnant women, children, old and immunocompromised persons; reduce tissue damage; and generate virus clearance through antibody-dependent cellular toxicity 


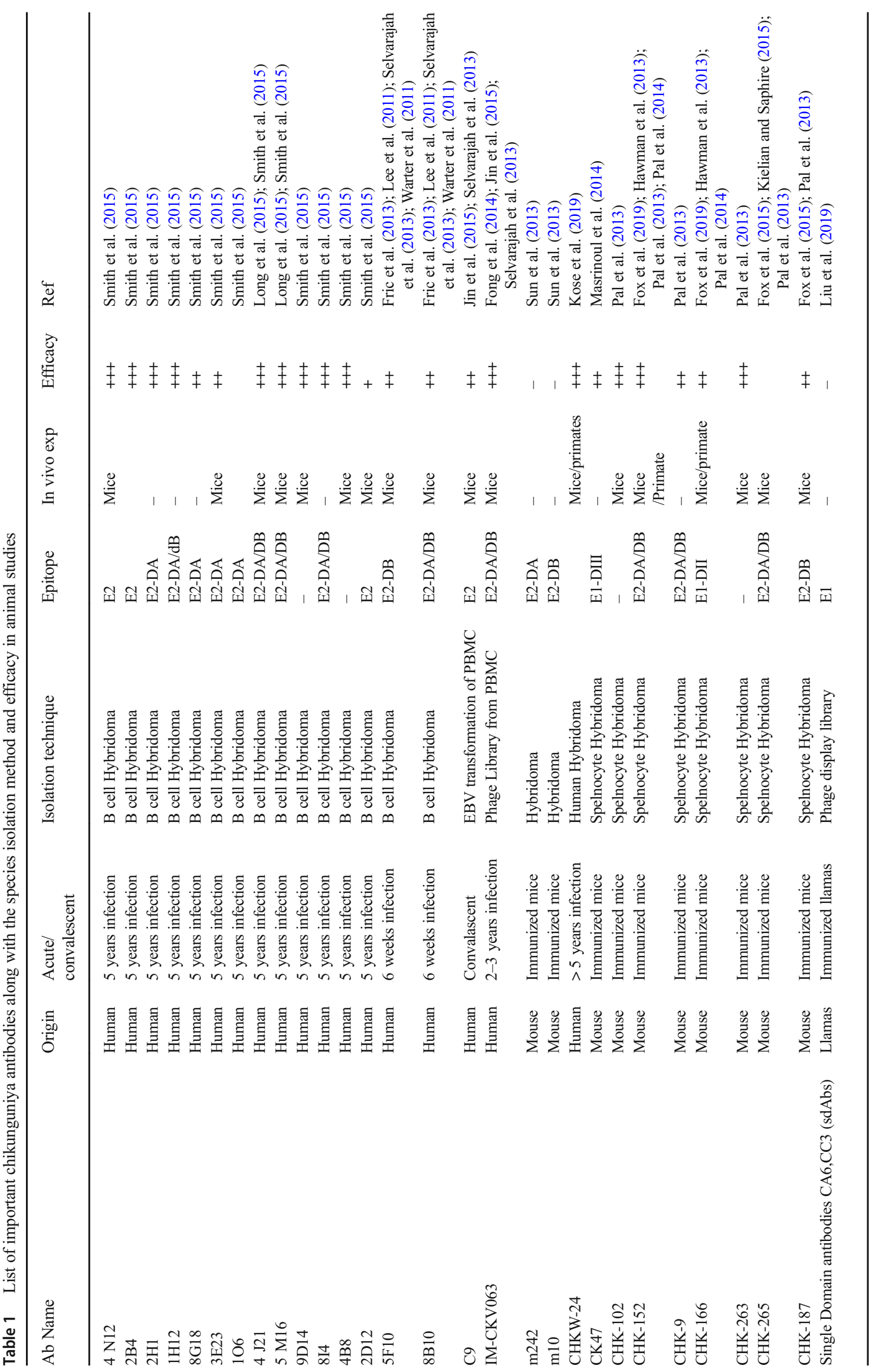


for binding to different antibodies. A representative binding interaction of one of the neutralizing antibodies has been shown in Fig. 5 a, b.

The E2 domain of CHIKV is conserved among different CHIKV lineage viruses and also among other alphaviruses i.e. ONNV, MAYV, RRV and SFV. Based on amino acid sequence similarity, MAYV is $60 \%$, ONNV is $86 \%$ and SFV and RRV are $57.6 \%$ identical to CHIKV (Fox et al. 2015; Kim et al. 2019). Passive transfer of broadly neutralizing mAbs targeting E2 domain CHIKV has shown in vivo protection in mice infected with CHIKV and other related alphaviruses. These antigenic conserved targets in the alphavirus B domain can potentially serve as a magic bullet for effective MAb therapies against CHIKV and other alphaviruses. This could also provide great insight into a reverse vaccinology strategy to design and develop vaccine targeting multiple alphaviruses of public health concern.

In addition, the basic feature of CHIKV that makes it an attractive target for antibody-based therapeutics is the presence of a high number of average envelope functional spikes (70-80) on the viral surface. As the number of functional envelope spikes on the viral surface increases, its infectivity increases and susceptibility to neutralizing antibodies also increases and the reverse is also true. The common example of this mechanism is human immunodeficiency viruses (HIV) where average numbers of functional spikes are 10-15 per virion that makes HIV less efficient in the transmission process (Schiller and Chackerian 2014). In natural infection, only $10-20 \%$ of the infected individuals develop neutralizing antibodies, and these antibodies have high degree of somatic hyper mutations and poly reactivity/auto reactivity to host proteins (Kumar et al. 2018; Liu et al. 2015; Patil et al. 2016) due to low density of the epitope spacing (Schiller and Chackerian 2014). Induction of such antibodies by vaccination is nearly impractical task. In the case of CHIKV infection, $>80 \%$ of the infected individuals develop neutralizing antibodies with less diverse somatic hypermutations. Researchers have used virus immune evade strategy for vaccine development of human papillomavirus (HPV). Virus-like particles (VLPs)based vaccine for HPV is the most successful example of this. Vaccination with HPV VLPs induces a robust neutralizing immune response (Safaeian et al. 2013). Similar strategies are under evaluation in CHIKV to explore the role of high-density envelope spikes to develop therapeutic interventions.
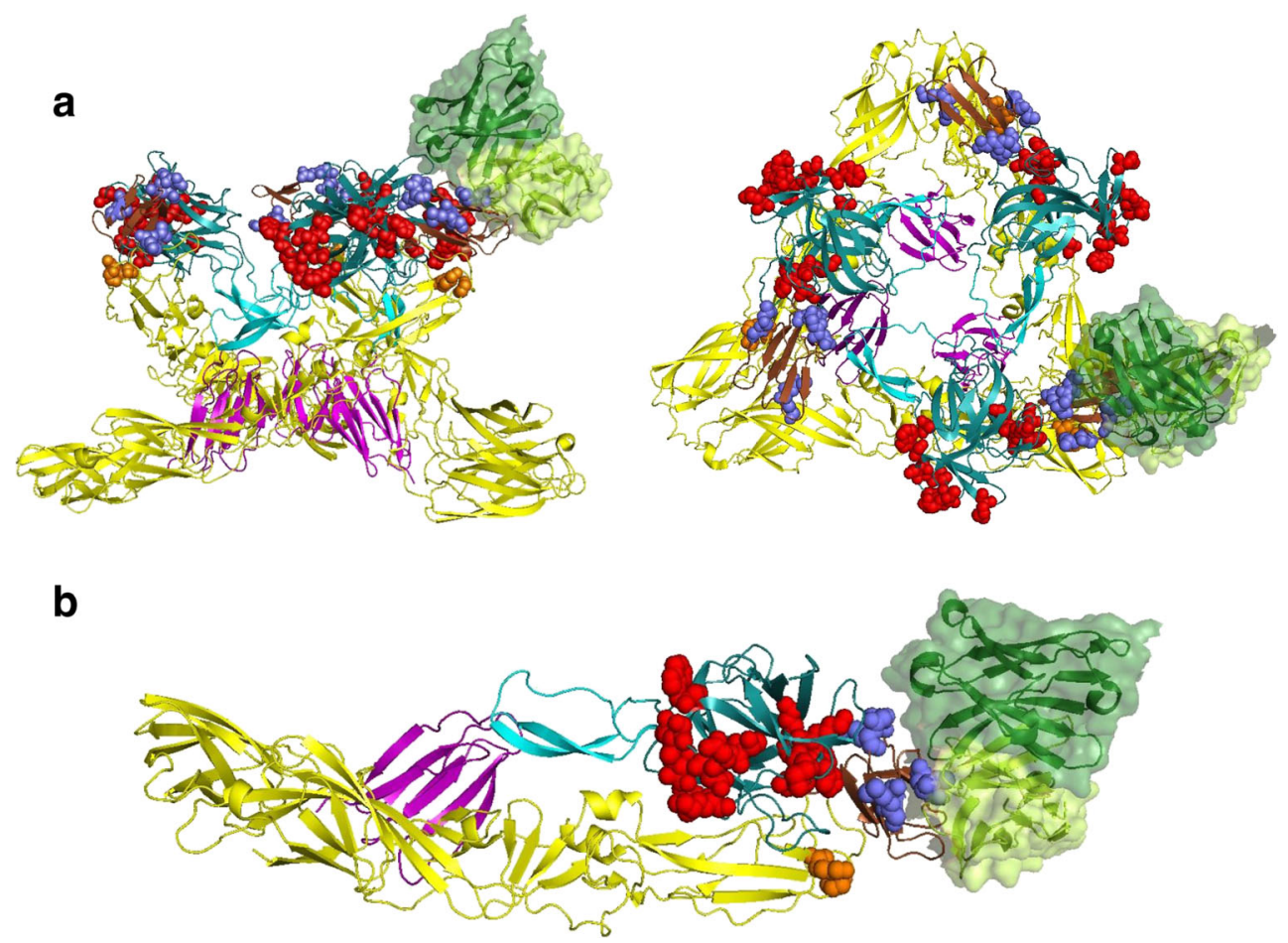

Fig. 5 a A ribbon trace of heterodimer of E1/E2 in trimeric conformation is shown with E1 in yellow and E2 in multiple color distinguishing domain A (DA) in teal, domain B (DB) in brown, domain C (DC) in magenta and the anchor in cyan color. The side chains of critical residues identified for binding to different $\mathrm{mAbs}$ are shown as space-filled forms and color-coded as red (residues in E2-DA) and blue (residues in E2-DB). A representative binding of antibody CHK-265 to the E2-DB is shown as surface representation. Each monomer of trimer can bind one such antibody that is removed for clarity. Figures are adopted based on PDB ID

5ANY. b A ribbon trace of a single heterodimer of E1/E2 is shown with $\mathrm{E} 1$ in yellow and E2 in multiple color distinguishing domain A (DA) in teal, domain $\mathrm{B}$ (DB) in brown, domain C (DC) in magenta and the anchor in cyan color. The side chains of critical residues identified for binding to different $\mathrm{mAbs}$ are shown as space-filled forms and color-coded as red (residues in E2-DA) and blue (residues in E2-DB). A representative binding of antibody CHK-265 to the E2-DB is shown as surface representation. Figure is adopted based on PDB ID 5ANY 


\section{Antibody-based therapeutic approaches and future prospects}

CHIKV has been reported to cause massive outbreaks of acute and chronic arthritis in humans. As of now, there is no specific treatment or vaccines available for CHIKV manifestation. Several potential small molecule-based antiviral therapeutic options are still in early examination stages (Parashar and Cherian 2014). Hence, the development of therapeutic and prophylactic strategies is an intimate and immediate need as a way to bridge the gap until effective vaccine or alternatives therapeutic options are available for treatment. It has been widely demonstrated that passive vaccination is an appropriate preventive and therapeutic option. In many viral diseases, hyperimmune human IgG is effectively used as a standard prevention therapy, for example, varicella-zoster and hepatitis B virus (Couderc et al. 2009). Additionally, these mAbs can be potentially used as a reagent for development of alternative rapid, low cost and affordable diagnostics for CHIKV infection as compared with the highcost PCR based methods. A lateral flow assay utilizing mAbs targeting the E1 protein has been developed for diagnosis of acute CHIKV infection (Yap et al. 2010).

In vitro and in vivo studies conducted using polyvalent human immunoglobulins from convalescent patients have demonstrated prophylactic and therapeutic efficacy from lethal CHIKV infections in new born mice. Similarly, purified neutralizing polyclonal antibodies from monkeys immunized with VLPs protected mice from the high-dose challenge of CHIKV (Akahata et al. 2010). Animal studies conducted on anti-CHIKV nAbs have shown that these nAbs can be potentially used both as therapeutically and prophylactically (Clayton 2016; Fric et al. 2013). It is well-known fact that CHIKV causes more severe disease in high-risk populations such as pregnant women, elderly patients, immunecompromised and patients with other underlying medical conditions. The prophylactic approach can be recommended in such high-risk groups (Fric et al. 2013; Tharmarajah et al. 2017). Recent reports on immunoglobulin (IVIg) therapeutics in human patients have shown hope for the path of antibodybased therapeutics and prophylactics. The prophylactic use of these antibodies might be useful in targeting restricted populations at high risk of complications like newborns especially born from viremic mother, pregnant women, heavily immunecompromised individuals, elderly individuals with preexisting medical complications and individuals with preexisting arthritis. Such tailor-made immunotherapy has applicability and potential as alternatives in outbreak situations. The therapeutic use of these antibody-based regimens will also be useful in patients infected with CHIKV or CHIKV with other comorbidities such as serious involvement of neurological complication and skin manifestations. There are studies that clearly demonstrate the effectiveness of IVIg as therapeutics (Couderc et al. 2009).
However, the prophylactic approach can be used as short term prevention strategy in CHIKV endemic areas to reduce the spread of disease. The major drawbacks of the prophylactic approach are that it requires multiple administrations; however, it can be used for specific periods in endemic areas where the probability of spreading of the disease is very high.

In a study by Scott et al. (2017), two patients infected with severe chikungunya encephalitis were treated with immunoglobulin (IVIg) (at a dose of $400 \mathrm{mg} / \mathrm{kg} /$ day for 5 days). A significant neurological improvement was observed in patients on fourth day of IVIg infusion, with complete recovery of the encephalitis (Scott et al. 2017). A similar report has recently been published by Fernandes et al. (2019) on the complete recovery of CHIKV-infected and presenting atypical dermatological disease after treatment with intravenous antibiotic and immunoglobulin therapy (Fernandes et al. 2019). The intravenous immunoglobulin (IVIg) therapy has also shown similar success results with other arboviruses (West Nile Virus) associated disease in human subjects (Hamdan et al. 2002). The success of IVIg in these studies validates the potential future use of anti-CHIKV-specific neutralizing antibodies as an excellent therapeutic and safe option for treating CHIKV-infected patients presenting atypical dermatological and neurological forms of the disease (Fernandes et al. 2019). A study was conducted on similar lines with purified IgGs from donors in the convalescent phase of CHIKV infection (CHIKVIg). The IgGs were purified from the patients exhibiting immunoreactivity in CHIKV IgG ELISA and neutralization assay. These purified CHIKVIg were used as pre- and post-exposure prophylaxis in immunocompromised adult mice and immunocompetent mice neonates and has shown protection against CHIKV challenge. The CHIKVIg treatment restricts the viral infection to the liver and prevents central nervous system (CNS) infection, which is the major cause of neurological manifestations (Couderc et al. 2009).

The potential effect of immunoglobulins/mAbs as prophylaxis is an effective medical intervention for reducing the severity of fatal events especially during birth of neonates from viremic mothers (Couderc and Lecuit 2015; Gerardin et al. 2008). An open Phase I/II nonrandomized trial (CHIKIVIG01 ) has been started to evaluate the safety and preliminarily assess the efficacy of anti-CHIKV hyperimmune human intravenous immunoglobulins as an intervention in children from viremic mothers for fatal events (Cardona-Correa et al. 2017) (https://clinicaltrials.gov/ct2/show/record/NCT02230163).

More recently, a combination of a disease-modifying antirheumatic drug (CTLA4-Ig) and an anti-CHIKV neutralizing human monoclonal antibody was used as therapeutics in acute CHIKV infection and arthritis in a C57BL/6 mouse model. A complete reduction in foot swelling and elimination of the virus was observed within a few days of treatment. Thus, a combination of anti-inflammatory immunomodulators along with 
antibody-based antiviral therapeutics may serve as a model for treating humans with arthritis caused by CHIKV or other related arbovirus. The immunomodulatory CTLA4-Ig blocks T cell costimulation and also have immunomodulatory effects on antigen-presenting cells (APCs) and provides greater impetus for treatment of viral diseases (Miner et al. 2017).

\section{Animal models in CHIKV therapy}

Animal models play important role in research and development for the approval of biologics license applications for $\mathrm{mAbs}$, vaccines and antiviral (Fig. 6). It is primarily necessary that these agents are tested in animal models, as preclinical animal testing is mandatory before the approval from by the US Food and Drug Administration (FDA) or European Agency for the Evaluation of Medicinal Products (EMEA).

The isolation of several monoclonal antibodies has increased the need to evaluate the efficacy and potency of mAbs in preclinical animal models. The availability of the experimental animal models such as mice and non-human primates to study CHIKV pathogenesis and disease progression have assisted testing of monoclonal antibodies for its therapeutics and prophylactic efficiency. Several groups have shown the use of these animal models for both prophylactic and therapeutic studies of mAbs testing (Haese et al. 2016).

For CHIKV mAbs, even though non-human primates (NHP) are the best models to test the efficacy of mAbs, few studies are conducted in NHP so far. Besides, the higher cost of NHP animal models poses major bottleneck of using this model in low- and middle-income countries (LMIC) where the CHIKV disease is endemic. Wild type mouse more closely recapitulates the human condition of chronic persistent infection of CHIKV, but the CHIKV persistence is less understood and the research in these areas is in the nascent stage. Immunocompromised/immunodeficient mice models are available for preliminary evaluation of $\mathrm{mAbs}$ as prophylactic or therapeutic interventions, though it is plausible that these mice are deficient of specific host immune components. Nevertheless, with a plethora of availability of immunological reagents in mice, it is easier and doable to readily test the mAbs efficacy in these mice. Presently, CHIKV research is understudied in the endemic LMIC areas; future research using these mice models will pave the way for the development of safe and robust mAb as CHIKV antiviral agent (Herrero et al. 2016).

\section{Use of wild type mice}

C57BL/6 J mice are highly susceptible to CHIKV infection and studied for arthritis model (Gardner et al. 2010). Jin et al. have used this mice model to test the neutralizing Abs (Nabs) against CHIKV-induced arthritis and infection (Jin et al. 2015). Inoculation of CHIKV into the footpad of wild type C57BL/6 mouse results in localized swelling, arthritis and fasciitis within foot and ankle; the development of these signs and symptoms aids in the evaluation of mAbs as antivirals. Pal et al. have shown that pre-treatment of mice with CHIKV mAbs completely protects the mice from the development of joint swelling (Pal et al. 2013). Other groups have also shown the therapeutics effects of CHIKV monoclonals in wild type mice (Broeckel et al. 2017; Fox et al. 2019). Using C57BL/6 J mice, the efficacy of human $\mathrm{C} 9 \mathrm{mAb}$ was checked against CHIKV infection-induced viremia and arthritis (Selvarajah et al. 2013).
Fig. 6 Graphical representation of in vivo mouse model for CHIKV mAb evaluation: Mice, non-human primates and immunodeficient mice are used to measure prophylactic or therapeutic potential of CHIKV mAbs. The promising $\mathrm{mAbs}$ could be used then for clinical trials in human

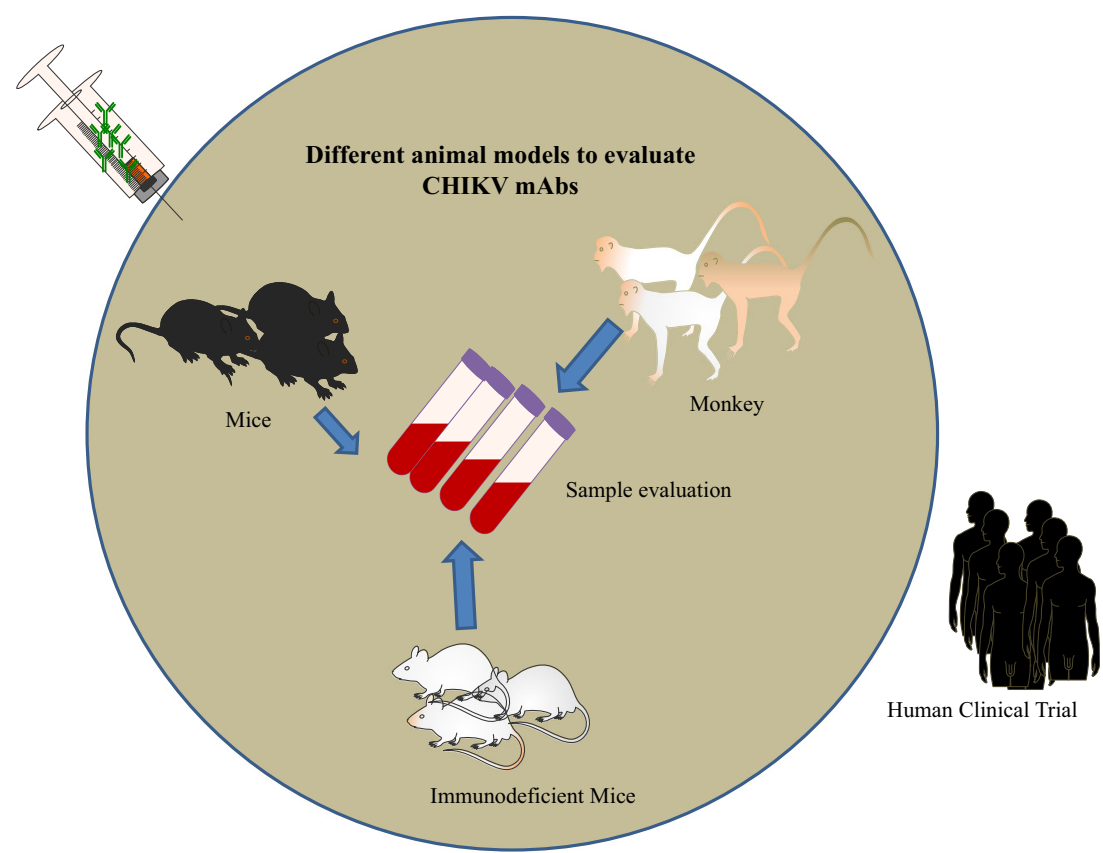




\section{Use of immunocompromised mice}

The immunocompromised mice such as neonatal mice, IFN- $\alpha / \beta$ receptor (IFNAR) knockout mice, AG129 mice deficient of interferon-alpha/beta/gamma receptor null (Type II Interferon) are highly susceptible models for CHIKV infections and show severe disease form (Couderc et al. 2008; Ziegler et al. 2008). The virus replicates in these mice with high titers and show symptoms similar to as observed in humans infected with CHIKV. Hence, the immunocompromised and/or immunodeficient mice are widely used for mAbs efficacy testing against CHIKV lethal and sub-lethal infection (Fong et al. 2014; Pal et al. 2013; Smith et al. 2015). Fric et al. have isolated and tested CHIKV mAbs 5F10 and 8B10 efficacy in vivo in AGR mice (Fric et al. 2013); whereas Lee et al. have used AGR129 immunocompromised mice for epitope mapping of CHIKV mAbs $5 \mathrm{~F} 10$ and 8B10 and to determine the infectivity of CHIKV neutralization-escape mutants (Lee et al. 2011). In some studies, researchers have also used RAG2 -/- I IFNAR1 -/- mice for measuring the prophylactic effect of mAbs against $\mathrm{CHIKV}$ infection. In these studies, the mice were pre-treated with CHIK mAbs and upon infection were found to be protected as compared with control mice showing lethal infection (Goh et al. 2013; Hawman et al. 2013). Both RAG1-/- and RAG2 $-/-$ mice, deficient of $B$ and $T$ cells, show persistent infection to CHIKV, which is a hallmark of CHIKV infection in humans with chronic joint pain. Prophylactic treatment of CHIKV $\mathrm{mAbs}$ in these mice has prevented the establishment of persistent CHIKV infection, whereas with therapeutic intervention showed efficacy to affected tissues (Hawman et al. 2013).

\section{Use of non-human primates}

NHP are excellent models to study CHIKV pathogenesis and preclinical testing of vaccines and therapeutics because they are naturally infected with CHIKV and show symptoms similar to human CHIKV infection. Furthermore, they are phylogenetically more homologous to humans than rodents. The first study of CHIKV using NHP was demonstrated by Ross; his group found that, when rhesus macaques were inoculated with CHIKV infected human sera, the macaques developed neutralizing antibodies (Ross 1956). Many studies in the NHP model are confined to understanding the fundamental science of CHIKV disease progression, immune response and testing of vaccines. Pal et al. has tested a combination of humanized mAbs CHK-152 and CHK-166 in rhesus macaques as postexposure therapeutic to CHIKV infection (Pal et al. 2014). In previous reports, these $\mathrm{mAbs}$ were protective against $\mathrm{CHIKV}$ using an Ifnar-/- mice (Pal et al. 2013). This study provides an insight of viral dissemination from the point of infection to different organs. An engineered mAb SVIR001, which mimics neutralizing anti-CHIKV human mAb 4 N12, have shown to reduced joint inflammation and virus clearance in CHIKV infected rhesus macaque model (Broeckel et al. 2017).

\section{Challenges associated with chikungunya therapeutic developments}

\section{Challenges of using nAbs for CHIKV and future expectancy}

Viruses can escape neutralizing antibody responses by undergoing genetic mutations that abolish antigen specificity and antigen-antibody binding or by indirect immune evasion strategies such as cell-to-cell transmission. These escape mutations are more frequent in RNA viruses. Lack of proofreading and repair mechanisms is responsible for the emergence of escape mutants under selective immune pressure (Drake and Holland 1999; Holland et al. 1982). The presence of RNA as a virtual genome in CHIKV puts the virus under scan of possible nucleotide sequence modification in selective pressure conditions like antibody therapy, antivirals etc. (Holland et al. 1982). Arboviruses are less prone to these changes due to their survival fitness and require replication in two taxonomically different hosts (Coffey et al. 2008; Lee et al. 2011). A number of neutralization-escape mutants have been reported for the alphavirus including CHIKV, Venezuelan equine encephalitis virus (VEE) (Johnson et al. 1990), sindbis virus (Stec et al. 1986) and RRV (Lee et al. 2011; Vrati et al. 1988). CHIKV is less likely to undergo genome modification, as evidenced by high nucleotide sequence conservation.

The use of combination of neutralizing mAbs targeting two different epitopes or by developing bispecific antibodies (Gardner et al. 2010; Jin et al. 2015) controls immune escape especially when administrated during the acute phase of viral infection, when viral load is very high and chances of emergence of resistant viral variant is very high (Kumar et al. 2018; Muller et al. 2009). In vitro studies have reported that escape mutants can be generated under selective pressure of mAbs (Gal-Tanamy et al. 2008; Lee et al. 2011). Although the proportion of these escape mutants is very low, these minor escape generates quasi-species and gets amplified under selective pressure (Kumar et al. 2018; Lee et al. 2011).

Presently high cost of antibody-based therapeutics intervention makes it difficult and challenging to target and protect a significant portion of the population infected with acute CHIKV. Recent advancement in gene transfer methods like adeno-associated virus (Balazs et al. 2014; Johnson et al. 2009) or DNA/RNA-based delivery methods (Kose et al. 2019; Pardi et al. 2017) has enabled injection to recipients with vectors encoding antibody gene sequences for rapid in vivo production of recombinant antibodies. Vector or nucleic acid coded for human antibodies has shown favorable effects in small animal models (Duperret et al. 2018; Muthumani et al. 2016). These approaches preclude the need 
for the complex manufacturing processes inherent in production and quality control of large amounts of recombinant monoclonal antibodies. The nucleic acid encoded antibodies can be manufactured speedily at much reduced cost than the equivalent protein therapeutics. This approach could revolutionize the feasibility of the widespread use of human $\mathrm{Ab}$ therapy and prophylaxis for emerging and re-emerging viral diseases like CHIK. Recent study conducted by Kose et al. (2019) on therapeutic efficiency of an infused nanoparticle encoding mRNA of CHIKV antibody with virus neutralizing activity has shown equivalent potency in protecting immunocompromised and immunocompetent mice, compared with the corresponding purified IgG form of the mAb (Kose et al. 2019). These studies provide a future expectancy for passive immunization or treatment of humans by administration of these nanoparticle based nucleic acid formulations encoding anti-CHIKV antibodies.

CHIKV has also been reported to exhibit cell to cell mode of transmission and escapes nAbs. The virus hides in different niche areas (reservoirs) of organs and tissues where extracellular antibodies cannot access these hidden reservoirs. The viral escape and reactivation happens as soon as the titer of nAbs drop extracellularly (Fric et al. 2013; Lee et al. 2011). The cell to cell transmission phenomenon is more common in the enveloped virus, which uses budding and exocytosis for release (Mothes et al. 2010).

Despite the protective role of neutralizing antibodies, there are not many studies on ADE that is a major concern in some of the flavivirus infections like dengue where suboptimal concentration of neutralizing antibodies has shown more severity of disease with subsequent infection with other serotypes (Halstead 2014; Langerak et al. 2019). Antibody-dependent enhancement (ADE) occurs when non-neutralizing or subneutralizing concentration of antibodies facilitates the virus to interact with host cell surface receptors and promotes entry into the target susceptible cells favoring viral replication (Lum et al. 2018). One of the key challenges associated with $\mathrm{mAb}$ therapeutic is the risk of ADE that aggravates the symptoms. The risk of ADE is associated with secondary infection caused by a heterologous or closely related virus from the same genus or family. Although the ADE phenomena is completely understood, it might arise as the viruses from the same or related family share some common epitopes. ADE is one of the most serious obstacles in therapeutic mAb development (Sun et al. 2017). Although one possible advantage of CHIKV is that it is a single viral serotype disease (Jin and Simmons 2019). However, ADE concern cannot be completely neglected especially with the possibility of the emergence of new quasispecies harboring mutations or co-infection/re-infection with other related alphaviruses. ADE has been observed in other viruses like influenza virus (Ochiai et al. 1992), rabies virus (King et al. 1984; Porterfield 1981), dengue virus (Morens and Halstead 1990), RRV (Lidbury and Mahalingam 2000), marburg virus (Nakayama et al. 2011) and HIV (Robinson Jr. et al. 1988). Until recently, among alphaviruses, virus enhancement was documented only in RRV infections. Recent studies conducted on in vitro and in vivo model systems has demonstrated enhanced infection of CHIKV in the presence of sub-neutralizing levels of anti-CHIKV antibodies obtained from CHIKV-infected patients or animals by extrinsic and intrinsic enhancement pathways. In extrinsic pathways, the virus binding and entry increases in the host cell without facilitating the active viral replication. Whereas, in intrinsic pathway, virus binding and entry along with active viral replication is accompanied by the alterations of host immune responses (Lum et al. 2018). The other alternative way to overcome concerns related to Fc-mediated processes of full length antibodies is to use single-chain variable fragments (Duperret et al. 2018) and single-domain antibodies (Mothes et al. 2010), as these are devoid of Fc portion of conventional antibodies however retaining the capacity of viral neutralization in absence of Fc portion (Duperret et al. 2018; Selvarajah et al. 2013).

The other critical limitations associated with antibodybased therapeutics for viral disease is the timing and frequency of therapeutic antibody administration. The antibody therapy works best if it is administrated early during acute phase of infection when viral load is very high. Administration of exogenous antibodies once an infection is established is of less use. Early diagnostics of viral diseases can make antibodybased therapeutics more for practical use (Parashar and Cherian 2014; Srinivasan et al. 2016).

Antibodies can be administrated as prophylactic measures during an epidemic to prevent deaths and the spread of disease. Administration of these antibodies can provide immediate immunity and can prevent the severity of the epidemic. The main challenge with prophylactic administration of these antibodies is that serum half-life of these antibodies is around 10-14 days, so repeated dosing will be required in an extended epidemic (Parashar and Cherian 2014). Recently, engineering of antibodies for their extended half-life has overcome these challenges. The engineered antibodies have their serum half-life extended up to several weeks (Booth et al. 2018). One such known example is the use of engineered antibodies with an extended half-life (up to 70 days) for respiratory syncytial virus (RSV) disease. The single dose of this antibody was found to be effective and protective against RSV for the duration of a typical 5-month season (Domachowske et al. 2018).

\section{Challenges associated with vaccine development strategies}

The ultimate goal for viral vaccine development is to design an effective vaccine candidate that can potentially elicit broadly neutralizing antibodies that can neutralize most strains of a virus. These broadly neutralizing antibodies function by 
binding to conserved receptor binding sites or domains, glycans, stem regions or trimer and dimer contacts of the envelope glycoprotein (Corti and Lanzavecchia 2013; Fox et al. 2015).

Antibody enhancement and other limitations associated with antibodies as therapeutic advocates the need for careful vaccine design and extensive pre-clinical trials before launching a vaccine. This also necessitates the careful selection of sites where these clinical trials are to be done (geographic location and outbreak predictions) to avoid undesired effects in anti-CHIKV vaccine design (Lum et al. 2018). Antibody induction through vaccination, enhancing or neutralizing will depend on numerous factors such as possible future infection with closely related viruses, the virus strain (serotype or genotype), virus titer and concentrations, conserved epitopes specificities, isotypes and FcRs-binding affinities of the antibodies (Boonnak et al. 2008; Hohdatsu et al. 1994; Lum et al. 2018; Midgley et al. 2012; Takada and Kawaoka 2003). Infants born to mothers infected with CHIKV or related virus during their pregnancy may suffer from disease severity due to the low levels of maternalacquired anti-CHIKV antibody escape mutants (Ng et al. 2014). Co-infection of related viruses (ZIKA and dengue) can cause more severe disease complications in endemic areas with the possibility of ADE. The pre-existing of ZIKV infection followed by CHIKV infection or ZIKV-CHIKV co-infection increases the incidence of neurological complications (Hermanns et al. 2018; Rothan et al. 2018).

The secondary infections in these endemic areas could probably be a major factor responsible for potentiating ADE response that, in turn, might be an important factor for the severity of subsequent arbovirus infection (Fernandes et al. 2019; Kam et al. 2015). This alarms the need for surveillance studies in alpha virus endemic areas before introducing a new vaccine.

A number of vaccine candidates are tested in animal models including non-human primate model and are in phase 1 and 2 studies (Hallengard et al. 2014). The protection mediated by these vaccine candidates is primarily due to humoral immune response. The further development of these vaccine candidates for the future depends on technical and economic measures that may pose obstacles for the development of safe and effective vaccines (Metz et al. 2013; Piper et al. 2013). CHIKV outbreak usually occurs sporadically and is unpredictable and leads to challenges for planning and execution of large phase 2 and 3 randomized controlled trials (RCTs). Identification of long-lasting markets for CHIKV vaccine is a challenge for investing commercial in firms because of the low fatality rate and its epidemic patterns (Rezza 2015; Rezza and Weaver 2019).

Elderly patients are more prone to infections, and vaccination in this subgroup is challenging due to immune senescence, which reduces the number of circulating immune cells like antigen-presenting cells (APCs), phagocytosis, naïve B and $T$ cells and toll-like receptor signaling pathways. Recent study conducted on VLP-based vaccine showing $100 \%$ protection in adult mice surprisingly exacerbated the CHIKV infection in aged mice (Arevalo et al. 2019). This study gives us a clue that introduction of vaccines in different subsets of populations needs to be evaluated before the introduction.

\section{Conclusions}

Chikungunya virus is transmitted by mosquitoes and in recent years has emerged and reemerged into the new global territories, posing significant threat to global health and heavy economic burden on national health care system. The CHIKV infection causes severe arthritis from acute stage of severe joint inflammation to chronic debilitating and persistent joint infection and other complications such as severe myocarditis and encephalitis. There is an urgent need for the development of alternate bio-therapeutics countermeasures to emerging viral infections to which no licensed vaccines or anti-viral drugs are available. Various potential small molecule-based antiviral therapeutic options are still in early examination stages. Development of vaccines and antibodybased therapeutics is associated with various limitations and challenges. Few vaccine candidates are tested in animal models including non-human primate model and have reached phase 1 and 2 studies. Passive transfer of antibodies in animal models has shown protection against lethal CHIKV infection. However, future expectancy from therapeutic options required a close monitoring of chikungunya natural infection.

Acknowledgments We thank Dr. Kaustav in preparation of Figs. 2 and 3.

Author contributions RK wrote the paper and finalized. TS, HAP and SS edited the manuscript; RK designed Figs. 2 and 3; SS and HAP designed Figs. 1, 4 and 6; and SA designed Fig. 5 and Table 1.

Funding information This work was supported by Translational Health Science and Technology Institute core grant.

\section{Compliance with ethical standards}

Conflict of interest The authors declare that they have no conflict of interest.

Ethical statement This article does not contain any studies with animals performed by any of the authors.

\section{References}

Akahata W, Yang ZY, Andersen H, Sun S, Holdaway HA, Kong WP, Lewis MG, Higgs S, Rossmann MG, Rao S, Nabel GJ (2010) A virus-like particle vaccine for epidemic chikungunya virus protects 
nonhuman primates against infection. Nat Med 16(3):334-338. https://doi.org/10.1038/nm.2105

Arevalo MT, Huang Y, Jones CA, Ross TM (2019) Vaccination with a chikungunya virus-like particle vaccine exacerbates disease in aged mice. PLoS Negl Trop Dis 13(4):e0007316. https://doi.org/10.1371/ journal.pntd.0007316

Balazs AB, Ouyang Y, Hong CM, Chen J, Nguyen SM, Rao DS, An DS, Baltimore D (2014) Vectored immunoprophylaxis protects humanized mice from mucosal HIV transmission. Nat Med 20(3):296-300. https://doi.org/10.1038/nm.3471

Barr KL, Vaidhyanathan V (2019) Chikungunya in infants and children: is pathogenesis increasing? Viruses 11

Berkelman RL, Bryan RT, Osterholm MT, LeDuc JW, Hughes JM (1994) Infectious disease surveillance: a crumbling foundation. Science 264(5157):368-370

Bhooshan S, Gandhi KK, Godbole M, Dole SS, Kapur S, Prajna Satpathy AMK, Deshpande PS, Azad F, Gupte N, Bharadwaj R, Bollinger RC, Gupta A (2015) Dengue and Chikungunya co-infection associated with more severe clinical disease than mono-infection. Int $\mathrm{J}$ Healthc Biomed Res 03(03):117-123

Blutt SE, Conner ME (2013) The gastrointestinal frontier: IgA and viruses. Front Immunol 4:402. https://doi.org/10.3389/fimmu.2013. 00402

Boonnak K, Slike BM, Burgess TH, Mason RM, Wu SJ, Sun P, Porter K, Rudiman IF, Yuwono D, Puthavathana P, Marovich MA (2008) Role of dendritic cells in antibody-dependent enhancement of dengue virus infection. J Virol 82(8):3939-3951. https://doi.org/10. 1128/JVI.02484-07

Booth BJ, Ramakrishnan B, Narayan K, Wollacott AM, Babcock GJ, Shriver Z, Viswanathan K (2018) Extending human IgG half-life using structure-guided design. MAbs 10(7):1098-1110. https://doi. org/10.1080/19420862.2018.1490119

Broeckel R, Fox JM, Haese N, Kreklywich CN, Sukulpovi-Petty S, Legasse A, Smith PP, Denton M, Corvey C, Krishnan S, Colgin LMA, Ducore RM, Lewis AD, Axthelm MK, Mandron M, Cortez P, Rothblatt J, Rao E, Focken I, Carter K, Sapparapau G, Crowe JE Jr, Diamond MS, Streblow DN (2017) Therapeutic administration of a recombinant human monoclonal antibody reduces the severity of chikungunya virus disease in rhesus macaques. PLoS Negl Trop Dis 11(6):e0005637. https://doi.org/10.1371/journal.pntd.0005637

Burt FJ, Chen W, Miner JJ, Lenschow DJ, Merits A, Schnettler E, Kohl A, Rudd PA, Taylor A, Herrero LJ, Zaid A, Ng LFP, Mahalingam S (2017) Chikungunya virus: an update on the biology and pathogenesis of this emerging pathogen. Lancet Infect Dis 17(4):e107-e117. https://doi.org/10.1016/S14733099(16)30385-1

Campos GS, Albuquerque Bandeira AC, Diniz Rocha VF, Dias JP, Carvalho RH, Sardi SI (2017) First detection of chikungunya virus in breast milk. Pediatr Infect Dis J 36(10):1015-1017. https://doi. org/10.1097/INF.0000000000001658

Cardona-Correa SE, Castano-Jaramillo LM, Quevedo-Velez A (2017) Vertical transmission of chikungunya virus infection. Case report. Rev Chil Pediatr 88(2):285-288. https://doi.org/10.4067/S037041062017000200015

Chandak NH, Kashyap RS, Kabra D, Karandikar P, Saha SS, Morey SH, Purohit HJ, Taori GM, Daginawala HF (2009) Neurological complications of Chikungunya virus infection. Neurol India 57:177-180

Charrel RN, de Lamballerie X, Raoult D (2007) Chikungunya outbreaksthe globalization of vectorborne diseases. N Engl J Med 356(8): 769-771. https://doi.org/10.1056/NEJMp078013

Chow A, Her Z, Ong EK, Chen JM, Dimatatac F, Kwek DJ, Barkham T, Yang H, Renia L, Leo YS, Ng LF (2011) Persistent arthralgia induced by Chikungunya virus infection is associated with interleukin-6 and granulocyte macrophage colony-stimulating factor. J Infect Dis 203:149-157
Chua CL, Sam IC, Chiam CW, Chan YF (2017) The neutralizing role of IgM during early chikungunya virus infection. PLoS One 12(2): e0171989. https://doi.org/10.1371/journal.pone.0171989

Clayton AM (2016) Monoclonal antibodies as prophylactic and therapeutic agents against chikungunya virus. J Infect Dis 214(suppl 5): S506-S509. https://doi.org/10.1093/infdis/jiw324

Coffey LL, Vasilakis N, Brault AC, Powers AM, Tripet F, Weaver SC (2008) Arbovirus evolution in vivo is constrained by host alternation. Proc Natl Acad Sci U S A 105(19):6970-6975. https://doi.org/ 10.1073/pnas.0712130105

Corti D, Lanzavecchia A (2013) Broadly neutralizing antiviral antibodies. Annu Rev Immunol 31:705-742. https://doi.org/10.1146/annurevimmunol-032712-095916

Couderc T, Lecuit M (2015) Chikungunya virus pathogenesis: from bedside to bench. Antivir Res 121:120-131. https://doi.org/10.1016/j. antiviral.2015.07.002

Couderc T, Chretien F, Schilte C, Disson O, Brigitte M, GuivelBenhassine F, Touret Y, Barau G, Cayet N, Schuffenecker I, Despres P, Arenzana-Seisdedos F, Michault A, Albert ML, Lecuit M (2008) A mouse model for chikungunya: young age and inefficient type-I interferon signaling are risk factors for severe disease. PLoS Pathog 4(2):e29. https://doi.org/10.1371/journal.ppat. 0040029

Couderc T, Khandoudi N, Grandadam M, Visse C, Gangneux N, Bagot S, Prost JF, Lecuit M (2009) Prophylaxis and therapy for chikungunya virus infection. J Infect Dis 200(4):516-523. https://doi.org/10. $1086 / 600381$

Couderc T, Gangneux N, Chretien F, Caro V, Le Luong T, Ducloux B, Tolou H, Lecuit M, Grandadam M (2012) Chikungunya virus infection of corneal grafts. J Infect Dis 206(6):851-859. https://doi.org/ 10.1093/infdis/jis296

Diallo D, Sall AA, Buenemann M, Chen R, Faye O, Diagne CT, Faye O, Ba Y, Dia I, Watts D, Weaver SC, Hanley KA, Diallo M (2012) Landscape ecology of sylvatic chikungunya virus and mosquito vectors in southeastern Senegal. PLoS Negl Trop Dis 6(6):e1649. https://doi.org/10.1371/journal.pntd.0001649

Dinkar A, Singh J, Prakash P, Das A, Nath G (2018) Hidden burden of chikungunya in North India; a prospective study in a tertiary care centre. J Infect Public Health 11(4):586-591. https://doi.org/10. 1016/j.jiph.2017.09.008

Domachowske JB, Khan AA, Esser MT, Jensen K, Takas T, Villafana T, Dubovsky F, Griffin MP (2018) Safety, tolerability and pharmacokinetics of MEDI8897, an extended half-life single-dose respiratory syncytial virus prefusion F-targeting monoclonal antibody administered as a single dose to healthy preterm infants. Pediatr Infect Dis J 37(9):886-892. https://doi.org/10.1097/INF.0000000000001916

Drake JW, Holland JJ (1999) Mutation rates among RNA viruses. Proc Natl Acad Sci U S A 96(24):13910-13913. https://doi.org/10.1073/ pnas.96.24.13910

Dunman PM, Nesin M (2003) Passive immunization as prophylaxis: when and where will this work? Curr Opin Pharmacol 3(5):486-496

Duperret EK, Trautz A, Stoltz R, Patel A, Wise MC, Perales-Puchalt A, Smith T, Broderick KE, Masteller E, Kim JJ, Humeau L, Muthumani K, Weiner DB (2018) Synthetic DNA-encoded monoclonal antibody delivery of anti-CTLA-4 antibodies induces tumor shrinkage in vivo. Cancer Res 78(22):6363-6370. https://doi.org/ 10.1158/0008-5472.CAN-18-1429

Economopoulou A, Dominguez M, Helynck B, Sissoko D, Wichmann O, Quenel P, Germonneau P, Quatresous I (2009) Atypical Chikungunya virus infections: clinical manifestations, mortality and risk factors for severe disease during the 2005-2006 outbreak on Reunion. Epidemiol Infect 137:534-541

Englund JA (2007) The influence of maternal immunization on infant immune responses. J Comp Pathol 137(Suppl 1):S16-S19. https:// doi.org/10.1016/j.jcpa.2007.04.006 
Erasmus JH, Rossi SL, Weaver SC (2016) Development of vaccines for chikungunya fever. J Infect Dis 214(suppl 5):S488-S496. https:// doi.org/10.1093/infdis/jiw271

Fernandes AIV, Souza JR, Silva AR, Cruz S, Castellano LRC (2019) Immunoglobulin therapy in a patient with severe chikungunya fever and vesiculobullous lesions. Front Immunol 10:1498. https://doi. org/10.3389/fimmu.2019.01498

Fong RH, Banik SS, Mattia K, Barnes T, Tucker D, Liss N, Lu K, Selvarajah S, Srinivasan S, Mabila M, Miller A, Muench MO, Michault A, Rucker JB, Paes C, Simmons G, Kahle KM, Doranz BJ (2014) Exposure of epitope residues on the outer face of the chikungunya virus envelope trimer determines antibody neutralizing efficacy. J Virol 88(24):14364-14379. https://doi.org/10.1128/JVI. 01943-14

Fox JM, Long F, Edeling MA, Lin H, van Duijl-Richter MKS, Fong RH, Kahle KM, Smit JM, Jin J, Simmons G, Doranz BJ, Crowe JE Jr, Fremont DH, Rossmann MG, Diamond MS (2015) Broadly neutralizing alphavirus antibodies bind an epitope on E2 and inhibit entry and egress. Cell 163(5):1095-1107. https://doi.org/10.1016/j.cell. 2015.10.050

Fox JM, Roy V, Gunn BM, Huang L, Edeling MA, Mack M, Fremont DH, Doranz BJ, Johnson S, Alter G, Diamond MS (2019) Optimal therapeutic activity of monoclonal antibodies against chikungunya virus requires Fc-FcgammaR interaction on monocytes. Sci Immunol 4(32) doi:https://doi.org/10.1126/sciimmunol.aav5062

Freitas ARR, Donalisio MR, Alarcon-Elbal PM (2018) Excess mortality and causes associated with chikungunya, Puerto Rico, 2014-2015. Emerg Infect Dis 24(12):2352-2355. https://doi.org/10.3201/ eid2412.170639

Fric J, Bertin-Maghit S, Wang CI, Nardin A, Warter L (2013) Use of human monoclonal antibodies to treat chikungunya virus infection. J Infect Dis 207(2):319-322. https://doi.org/10.1093/infdis/jis674

Gal-Tanamy M, Keck ZY, Yi M, McKeating JA, Patel AH, Foung SK, Lemon SM (2008) In vitro selection of a neutralization-resistant hepatitis C virus escape mutant. Proc Natl Acad Sci U S A 105(49):19450-19455. https://doi.org/10.1073/pnas.0809879105

Gardner J, Anraku I, Le TT, Larcher T, Major L, Roques P, Schroder WA, Higgs S, Suhrbier A (2010) Chikungunya virus arthritis in adult wild-type mice. J Virol 84(16):8021-8032. https://doi.org/10.1128/ JVI.02603-09

Gerardin P, Barau G, Michault A, Bintner M, Randrianaivo H, Choker G, Lenglet Y, Touret Y, Bouveret A, Grivard P, Le Roux K, Blanc S, Schuffenecker I, Couderc T, Arenzana-Seisdedos F, Lecuit M, Robillard PY (2008) Multidisciplinary prospective study of mother-to-child chikungunya virus infections on the island of $\mathrm{La}$ Reunion. PLoS Med 5(3):e60. https://doi.org/10.1371/journal. pmed.0050060

Go YY, Balasuriya UB, Lee CK (2014) Zoonotic encephalitides caused by arboviruses: transmission and epidemiology of alphaviruses and flaviviruses. Clin Exp Vaccine Res 3(1):58-77. https://doi.org/10. 7774/cevr.2014.3.1.58

Goh LY, Hobson-Peters J, Prow NA, Gardner J, Bielefeldt-Ohmann H, Pyke AT, Suhrbier A, Hall RA (2013) Neutralizing monoclonal antibodies to the E2 protein of chikungunya virus protects against disease in a mouse model. Clin Immunol 149(3):487-497. https:// doi.org/10.1016/j.clim.2013.10.004

Haese NN, Broeckel RM, Hawman DW, Heise MT, Morrison TE, Streblow DN (2016) Animal models of chikungunya virus infection and disease. J Infect Dis 214(suppl 5):S482-S487. https://doi.org/ 10.1093/infdis/jiw284

Hallengard D, Kakoulidou M, Lulla A, Kummerer BM, Johansson DX, Mutso M, Lulla V, Fazakerley JK, Roques P, Le Grand R, Merits A, Liljestrom P (2014) Novel attenuated chikungunya vaccine candidates elicit protective immunity in C57BL/6 mice. J Virol 88(5): 2858-2866. https://doi.org/10.1128/JVI.03453-13
Halstead SB (2014) Dengue antibody-dependent enhancement: knowns and unknowns. Microbiol Spectr 2(6) doi:https://doi.org/10.1128/ microbiolspec.AID-0022-2014

Hamdan A, Green P, Mendelson E, Kramer MR, Pitlik S, Weinberger M (2002) Possible benefit of intravenous immunoglobulin therapy in a lung transplant recipient with West Nile virus encephalitis. Transpl Infect Dis 4(3):160-162

Hardy JL, Houk EJ, Kramer LD, Reeves WC (1983) Intrinsic factors affecting vector competence of mosquitoes for arboviruses. Annu Rev Entomol 28:229-262. https://doi.org/10.1146/annurev.en.28. 010183.001305

Hawman DW, Stoermer KA, Montgomery SA, Pal P, Oko L, Diamond MS, Morrison TE (2013) Chronic joint disease caused by persistent chikungunya virus infection is controlled by the adaptive immune response. J Virol 87(24):13878-13888. https://doi.org/10.1128/JVI. 02666-13

Hermanns K, Gohner C, Kopp A, Schmidt A, Merz WM, Markert UR, Junglen S, Drosten C (2018) Zika virus infection in human placental tissue explants is enhanced in the presence of dengue virus antibodies in-vitro. Emerg Microbes Infect 7(1):198. https://doi.org/10. 1038/s41426-018-0199-6

Herrero LJ, Rudd PA, Liu X, Wolf S, Mahalingam S (2016) Mouse models of chikungunya virus. Methods Mol Biol 1426:211-224. https://doi.org/10.1007/978-1-4939-3618-2_19

Hey A (2015) History and practice: antibodies in infectious diseases. Microbiol Spectr 3(2):AID-0026-2014 doi:https://doi.org/10.1128/ microbiolspec.AID-0026-2014

Hirano T, Taga T, Nakano N, Yasukawa K, Kashiwamura S, Shimizu K, Nakajima K, Pyun KH, Kishimoto T (1985) Purification to homogeneity and characterization of human B-cell differentiation factor (BCDF or BSFp-2). Proc Natl Acad Sci U S A 82(16):5490-5494. https://doi.org/10.1073/pnas.82.16.5490

Hoarau JJ, Jaffar Bandjee MC, Krejbich Trotot P, Das T, Li-Pat-Yuen G, Dassa B, Denizot M, Guichard E, Ribera A, Henni T, Tallet F, Moiton MP, Gauzere BA, Bruniquet S, Jaffar Bandjee Z, Morbidelli P, Martigny G, Jolivet M, Gay F, Grandadam M, Tolou H, Vieillard V, Debre P, Autran B, Gasque P (2010) Persistent chronic inflammation and infection by chikungunya arthritogenic alphavirus in spite of a robust host immune response. J Immunol 184(10):5914-5927. https://doi.org/10.4049/jimmunol.0900255

Hohdatsu T, Tokunaga J, Koyama H (1994) The role of IgG subclass of mouse monoclonal antibodies in antibody-dependent enhancement of feline infectious peritonitis virus infection of feline macrophages. Arch Virol 139(3-4):273-285

Holland J, Spindler K, Horodyski F, Grabau E, Nichol S, VandePol S (1982) Rapid evolution of RNA genomes. Science 215(4540): 1577-1585. https://doi.org/10.1126/science.7041255

Jin J, Simmons G (2019) Antiviral functions of monoclonal antibodies against chikungunya virus. Viruses 11(4). https://doi.org/10.3390/ v11040305

Jin J, Liss NM, Chen DH, Liao M, Fox JM, Shimak RM, Fong RH, Chafets D, Bakkour S, Keating S, Fomin ME, Muench MO, Sherman MB, Doranz BJ, Diamond MS, Simmons G (2015) Neutralizing monoclonal antibodies block chikungunya virus entry and release by targeting an epitope critical to viral pathogenesis. Cell Rep 13(11):2553-2564. https://doi.org/10.1016/j.celrep.2015.11. 043

Johnson BJ, Brubaker JR, Roehrig JT, Trent DW (1990) Variants of Venezuelan equine encephalitis virus that resist neutralization define a domain of the E2 glycoprotein. Virology 177(2):676-683

Johnson PR, Schnepp BC, Zhang J, Connell MJ, Greene SM, Yuste E, Desrosiers RC, Clark KR (2009) Vector-mediated gene transfer engenders long-lived neutralizing activity and protection against SIV infection in monkeys. Nat Med 15(8):901-906. https://doi.org/10. 1038/nm.1967 
Josseran L, Paquet C, Zehgnoun A, Caillere N, Le Tertre A, Solet JL, Ledrans M (2006) Chikungunya disease outbreak, Reunion Island. Emerg Infect Dis 12:1994-1995

Kam YW, Lee WW, Simarmata D, Harjanto S, Teng TS, Tolou H, Chow A, Lin RT, Leo YS, Renia L, Ng LF (2012a) Longitudinal analysis of the human antibody response to chikungunya virus infection: implications for serodiagnosis and vaccine development. J Virol 86(23):13005-13015. https://doi.org/10.1128/JVI.01780-12

Kam YW, Lum FM, Teo TH, Lee WW, Simarmata D, Harjanto S, Chua CL, Chan YF, Wee JK, Chow A, Lin RT, Leo YS, Le Grand R, Sam IC, Tong JC, Roques P, Wiesmuller KH, Renia L, Rotzschke O, Ng LF (2012b) Early neutralizing IgG response to chikungunya virus in infected patients targets a dominant linear epitope on the E2 glycoprotein. EMBO Mol Med 4(4):330-343. https://doi.org/10.1002/ emmm.201200213

Kam YW, Simarmata D, Chow A, Her Z, Teng TS, Ong EK, Renia L, Leo YS, Ng LF (2012c) Early appearance of neutralizing immunoglobulin G3 antibodies is associated with chikungunya virus clearance and long-term clinical protection. J Infect Dis 205(7):11471154. https://doi.org/10.1093/infdis/jis033

Kam YW, Pok KY, Eng KE, Tan LK, Kaur S, Lee WW, Leo YS, Ng LC, $\mathrm{Ng}$ LF (2015) Sero-prevalence and cross-reactivity of chikungunya virus specific anti-E2EP3 antibodies in arbovirus-infected patients. PLoS Negl Trop Dis 9(1):e3445. https://doi.org/10.1371/journal. pntd.0003445

Kashyap RS, Morey SH, Chandak NH, Purohit HJ, Taori GM, Daginawala HF (2010) Detection of viral antigen, IgM and IgG antibodies in cerebrospinal fluid of Chikungunya patients with neurological complications. Cerebrospinal Fluid Res 7:12

Kawano Y, Noma T, Yata J (1994) Regulation of human IgG subclass production by cytokines. IFN-gamma and IL- 6 act antagonistically in the induction of human IgG1 but additively in the induction of IgG2. J Immunol 153(11):4948-4958

Kielian M, Saphire EO (2015) Potent antibody protection against an emerging alphavirus threat. Cell 163(5):1053-1054. https://doi. org/10.1016/j.cell.2015.11.006

Kim J, Yang J, Kim YB, Lee HJ, Kim S, Poo H (2019) Development of a specific CHIKV-E2 monoclonal antibody for chikungunya diagnosis. Virol Sin. https://doi.org/10.1007/s12250-019-00135-y

King AA, Sands JJ, Porterfield JS (1984) Antibody-mediated enhancement of rabies virus infection in a mouse macrophage cell line (P388D1). J Gen Virol 65(Pt 6):1091-1093. https://doi.org/10. 1099/0022-1317-65-6-1091

Kose N, Fox JM, Sapparapu G, Bombardi R, Tennekoon RN, de Silva AD, Elbashir SM, Theisen MA, Humphris-Narayanan E, Ciaramella G, Himansu S, Diamond MS, Crowe JE Jr (2019) A lipid-encapsulated mRNA encoding a potently neutralizing human monoclonal antibody protects against chikungunya infection. Sci Immunol 4(35). https://doi.org/10.1126/sciimmunol.aaw6647

Krishnamoorthy K, Harichandrakumar KT, Krishna Kumari A, Das LK (2009) Burden of chikungunya in India: estimates of disability adjusted life years (DALY) lost in 2006 epidemic. J Vector Borne Dis 46(1):26-35

Kumar R, Qureshi H, Deshpande S, Bhattacharya J (2018) Broadly neutralizing antibodies in HIV-1 treatment and prevention. Ther Adv Vaccines Immunother 6(4):61-68. https://doi.org/10.1177/ 2515135518800689

Labadie K, Larcher T, Joubert C, Mannioui A, Delache B, Brochard P, Guigand L, Dubreil L, Lebon P, Verrier B, de Lamballerie X, Suhrbier A, Cherel Y, Le Grand R, Roques P (2010) Chikungunya disease in nonhuman primates involves long-term viral persistence in macrophages. J Clin Invest 120(3):894-906. https://doi.org/10. 1172/JCI40104

Lam S, Nyo M, Phuektes P, Yew CW, Tan YJ, Chu JJ (2015) A potent neutralizing $\operatorname{IgM} \mathrm{mAb}$ targeting the $\mathrm{N} 218$ epitope on $\mathrm{E} 2$ protein protects against chikungunya virus pathogenesis. MAbs 7(6): 1178-1194. https://doi.org/10.1080/19420862.2015.1083664

Landry ML (2016) Immunoglobulin M for acute infection: true or false? Clin Vaccine Immunol 23(7):540-545. https://doi.org/10.1128/CVI. 00211-16

Langerak T, Mumtaz N, Tolk VI, van Gorp ECM, Martina BE, Rockx B, Koopmans MPG (2019) The possible role of cross-reactive dengue virus antibodies in Zika virus pathogenesis. PLoS Pathog 15(4): e1007640. https://doi.org/10.1371/journal.ppat.1007640

Lee CY, Kam YW, Fric J, Malleret B, Koh EG, Prakash C, Huang W, Lee WW, Lin C, Lin RT, Renia L, Wang CI, Ng LF, Warter L (2011) Chikungunya virus neutralization antigens and direct cell-to-cell transmission are revealed by human antibody-escape mutants. PLoS Pathog 7(12):e1002390. https://doi.org/10.1371/journal.ppat.1002390

Levade M, Maquin P, Rousseau H, Trocard J, Railhac JJ, Joffre F (1991) Percutaneous peripheral atherectomy with the Simpson catheter. Long term results. J Mal Vasc 16(2):193-194

Lidbury BA, Mahalingam S (2000) Specific ablation of antiviral gene expression in macrophages by antibody-dependent enhancement of Ross River virus infection. J Virol 74(18):8376-8381. https:// doi.org/10.1128/jvi.74.18.8376-8381.2000

Lim BN, Tye GJ, Choong YS, Ong EB, Ismail A, Lim TS (2014) Principles and application of antibody libraries for infectious diseases. Biotechnol Lett 36(12):2381-2392. https://doi.org/10.1007/ s10529-014-1635-x

Lin YS, Yeh TM, Lin CF, Wan SW, Chuang YC, Hsu TK, Liu HS, Liu CC, Anderson R, Lei HY (2011) Molecular mimicry between virus and host and its implications for dengue disease pathogenesis. Exp Biol Med (Maywood) 236:515-523

Lin SC, Shyur SD, Ma YC, Huang LH, Lee WI (2005) Hyper-IgM1 syndrome with interstitial pneumonia and diarrhea caused by coxsackievirus B4 in a 3-month-old infant. Ann Allergy Asthma Immunol 95(1):93-97. https://doi.org/10.1016/S1081-1206(10) 61194-5

Liu M, Yang G, Wiehe K, Nicely NI, Vandergrift NA, Rountree W, Bonsignori M, Alam SM, Gao J, Haynes BF, Kelsoe G (2015) Polyreactivity and autoreactivity among HIV-1 antibodies. J Virol 89(1):784-798. https://doi.org/10.1128/JVI.02378-14

Liu JL, Shriver-Lake LC, Zabetakis D, Anderson GP, Goldman ER (2019) Selection and characterization of protective antichikungunya virus single domain antibodies. Mol Immunol 105: 190-197. https://doi.org/10.1016/j.molimm.2018.11.016

Long F, Fong RH, Austin SK, Chen Z, Klose T, Fokine A, Liu Y, Porta J, Sapparapu G, Akahata W, Doranz BJ, Crowe JE Jr, Diamond MS, Rossmann MG (2015) Cryo-EM structures elucidate neutralizing mechanisms of anti-chikungunya human monoclonal antibodies with therapeutic activity. Proc Natl Acad Sci U S A 112(45): 13898-13903. https://doi.org/10.1073/pnas.1515558112

Lum FM, Couderc T, Chia BS, Ong RY, Her Z, Chow A, Leo YS, Kam YW, Renia L, Lecuit M, Ng LFP (2018) Antibody-mediated enhancement aggravates chikungunya virus infection and disease severity. Sci Rep 8(1):1860. https://doi.org/10.1038/s41598-01820305-4

Malvy D, Ezzedine K, Mamani-Matsuda M, Autran B, Tolou H, Receveur MC, Pistone T, Rambert J, Moynet D, Mossalayi D (2009) Destructive arthritis in a patient with chikungunya virus infection with persistent specific IgM antibodies. BMC Infect Dis 9: 200. https://doi.org/10.1186/1471-2334-9-200

Marston HD, Paules CI, Fauci AS (2018) Monoclonal antibodies for emerging infectious diseases - borrowing from history. N Engl J Med 378:1469-1472

Masrinoul P, Puiprom O, Tanaka A, Kuwahara M, Chaichana P, Ikuta K, Ramasoota P, Okabayashi T (2014) Monoclonal antibody targeting chikungunya virus envelope 1 protein inhibits virus release. Virology 464-465:111-117. https://doi.org/10.1016/j.virol.2014.05.038 
Matusali G, Colavita F, Bordi L, Lalle E, Ippolito G, Capobianchi MR, Castilletti C (2019) Tropism of the chikungunya virus. Viruses 11(2). https://doi.org/10.3390/v11020175

Mavalankar D, Shastri P, Bandyopadhyay T, Parmar J, Ramani KV (2008) Increased mortality rate associated with chikungunya epidemic, Ahmedabad, India. Emerg Infect Dis 14(3):412-415. https://doi.org/10.3201/eid1403.070720

Metz SW, Gardner J, Geertsema C, Le TT, Goh L, Vlak JM, Suhrbier A, Pijlman GP (2013) Effective chikungunya virus-like particle vaccine produced in insect cells. PLoS Negl Trop Dis 7(3):e2124. https://doi. org/10.1371/journal.pntd.0002124

Midgley CM, Flanagan A, Tran HB, Dejnirattisai W, Chawansuntati K, Jumnainsong A, Wongwiwat W, Duangchinda T, Mongkolsapaya J, Grimes JM, Screaton GR (2012) Structural analysis of a dengue cross-reactive antibody complexed with envelope domain III reveals the molecular basis of cross-reactivity. J Immunol 188(10):49714979. https://doi.org/10.4049/jimmunol.1200227

Miner JJ, Cook LE, Hong JP, Smith AM, Richner JM, Shimak RM, Young AR, Monte K, Poddar S, Crowe JE Jr, Lenschow DJ, Diamond MS (2017) Therapy with CTLA4-Ig and an antiviral monoclonal antibody controls chikungunya virus arthritis. Sci Transl Med 9(375). https://doi.org/10.1126/scitranslmed.aah3438

Morens DM, Halstead SB (1990) Measurement of antibody-dependent infection enhancement of four dengue virus serotypes by monoclonal and polyclonal antibodies. J Gen Virol 71(Pt 12):2909-2914. https://doi.org/10.1099/0022-1317-71-12-2909

Mothes W, Sherer NM, Jin J, Zhong P (2010) Virus cell-to-cell transmission. J Virol 84(17):8360-8368. https://doi.org/10.1128/JVI.00443-10

Muller T, Dietzschold B, Ertl H, Fooks AR, Freuling C, Fehlner-Gardiner C, Kliemt J, Meslin FX, Franka R, Rupprecht CE, Tordo N, Wanderler AI, Kieny MP (2009) Development of a mouse monoclonal antibody cocktail for post-exposure rabies prophylaxis in humans. PLoS Negl Trop Dis 3(11):e542. https://doi.org/10.1371/ journal.pntd.0000542

Muthumani K, Block P, Flingai S, Muruganantham N, Chaaithanya IK, Tingey C, Wise M, Reuschel EL, Chung C, Muthumani A, Sarangan G, Srikanth P, Khan AS, Vijayachari P, Sardesai NY, Kim JJ, Ugen KE, Weiner DB (2016) Rapid and Long-term immunity elicited by DNA-encoded antibody prophylaxis and DNA vaccination against chikungunya virus. J Infect Dis 214(3):369-378. https://doi.org/10.1093/infdis/jiw111

Nakayama E, Tomabechi D, Matsuno K, Kishida N, Yoshida R, Feldmann H, Takada A (2011) Antibody-dependent enhancement of Marburg virus infection. J Infect Dis 204(Suppl 3):S978-S985. https://doi.org/10.1093/infdis/jir334

Ng JK, Zhang SL, Tan HC, Yan B, Martinez JM, Tan WY, Lam JH, Tan GK, Ooi EE, Alonso S (2014) First experimental in vivo model of enhanced dengue disease severity through maternally acquired heterotypic dengue antibodies. PLoS Pathog 10(4):e1004031. https:// doi.org/10.1371/journal.ppat.1004031

Nitatpattana N, Kanjanopas K, Yoksan S, Satimai W, Vongba N, Langdatsuwan S, Nakgoi K, Ratchakum S, Wauquier N, Souris M, Auewarakul P, Gonzalez JP (2014) Long-term persistence of chikungunya virus neutralizing antibodies in human populations of north eastern Thailand. Virol J 11:183. https://doi.org/10.1186/ 1743-422X-11-183

Ochiai H, Kurokawa M, Matsui S, Yamamoto T, Kuroki Y, Kishimoto C, Shiraki K (1992) Infection enhancement of influenza A NWS virus in primary murine macrophages by anti-hemagglutinin monoclonal antibody. J Med Virol 36(3):217-221

Pal P, Dowd KA, Brien JD, Edeling MA, Gorlatov S, Johnson S, Lee I, Akahata W, Nabel GJ, Richter MK, Smit JM, Fremont DH, Pierson TC, Heise MT, Diamond MS (2013) Development of a highly protective combination monoclonal antibody therapy against chikungunya virus. PLoS Pathog 9(4):e1003312. https://doi.org/ 10.1371/journal.ppat.1003312
Pal P, Fox JM, Hawman DW, Huang YJ, Messaoudi I, Kreklywich C, Denton M, Legasse AW, Smith PP, Johnson S, Axthelm MK, Vanlandingham DL, Streblow DN, Higgs S, Morrison TE, Diamond MS (2014) Chikungunya viruses that escape monoclonal antibody therapy are clinically attenuated, stable, and not purified in mosquitoes. J Virol 88(15):8213-8226. https://doi.org/10.1128/JVI.01032-14

Palmeira P, Quinello C, Silveira-Lessa AL, Zago CA, Carneiro-Sampaio M (2012) IgG placental transfer in healthy and pathological pregnancies. Clin Dev Immunol 2012:985646. https://doi.org/10.1155/ 2012/985646

Parashar D, Cherian S (2014) Antiviral perspectives for chikungunya virus. Biomed Res Int 2014:631642. https://doi.org/10.1155/2014/ 631642

Pardi N, Secreto AJ, Shan X, Debonera F, Glover J, Yi Y, Muramatsu H, Ni H, Mui BL, Tam YK, Shaheen F, Collman RG, Kariko K, DanetDesnoyers GA, Madden TD, Hope MJ, Weissman D (2017) Administration of nucleoside-modified mRNA encoding broadly neutralizing antibody protects humanized mice from HIV-1 challenge. Nat Commun 8:14630. https://doi.org/10.1038/ ncomms 14630

Parola P, de Lamballerie X, Jourdan J, Rovery C, Vaillant V, Minodier P, Brouqui P, Flahault A, Raoult D, Charrel RN (2006) Novel chikungunya virus variant in travelers returning from Indian Ocean islands. Emerg Infect Dis 12(10):1493-1499. https://doi. org/10.3201/eid1210.060610

Patil S, Kumar R, Deshpande S, Samal S, Shrivastava T, Boliar S, Bansal M, Chaudhary NK, Srikrishnan AK, Murugavel KG, Solomon S, Simek M, Koff WC, Goyal R, Chakrabarti BK, Bhattacharya J (2016) Conformational epitope-specific broadly neutralizing plasma antibodies obtained from an HIV-1 clade C-infected elite neutralizer mediate autologous virus escape through mutations in the V1 loop. $\mathrm{J}$ Virol 90(7):3446-3457. https://doi.org/10.1128/JVI.03090-15

Pelfrene E, Mura M, Cavaleiro Sanches A, Cavaleri M (2018) Monoclonal antibodies as anti-infective products: a promising future? Clin Microbiol Infect. https://doi.org/10.1016/j.cmi.2018.04. 024

Petitdemange C, Wauquier N, Vieillard V (2015) Control of immunopathology during chikungunya virus infection. J Allergy Clin Immunol 135(4):846-855. https://doi.org/10.1016/j.jaci.2015.01.039

Pierro A, Rossini G, Gaibani P, Finarelli AC, Moro ML, Landini MP, Sambri V (2015) Persistence of anti-chikungunya virus-specific antibodies in a cohort of patients followed from the acute phase of infection after the 2007 outbreak in Italy. New Microbes New Infect 7:23-25. https://doi.org/10.1016/j.nmni.2015.04.002

Piper A, Ribeiro M, Smith KM, Briggs CM, Huitt E, Nanda K, Spears CJ, Quiles M, Cullen J, Thomas ME, Brown DT, Hernandez R (2013) Chikungunya virus host range E2 transmembrane deletion mutants induce protective immunity against challenge in C57BL/6J mice. $\mathrm{J}$ Virol 87(12):6748-6757. https://doi.org/10.1128/JVI.03357-12

Plante K, Wang E, Partidos CD, Weger J, Gorchakov R, Tsetsarkin K, Borland EM, Powers AM, Seymour R, Stinchcomb DT, Osorio JE, Frolov I, Weaver SC (2011) Novel chikungunya vaccine candidate with an IRES-based attenuation and host range alteration mechanism. PLoS Pathog 7(7):e1002142. https://doi.org/10.1371/journal. ppat. 1002142

Porterfield JS (1981) Antibody-mediated enhancement of rabies virus. Nature 290(5807):542. https://doi.org/10.1038/290542a0

Powers AM (2018) Vaccine and therapeutic options to control chikungunya virus. Clin Microbiol Rev 31(1). https://doi.org/10. 1128/CMR.00104-16

Powers AM, Logue CH (2007) Changing patterns of chikungunya virus: re-emergence of a zoonotic arbovirus. J Gen Virol 88(Pt 9):23632377. https://doi.org/10.1099/vir.0.82858-0

Qiao X, He B, Chiu A, Knowles DM, Chadburn A, Cerutti A (2006) Human immunodeficiency virus $1 \mathrm{Nef}$ suppresses CD40-dependent 
immunoglobulin class switching in bystander B cells. Nat Immunol 7(3):302-310. https://doi.org/10.1038/ni1302

Reddy V, Desai A, Krishna SS, Vasanthapuram R (2017) Molecular mimicry between Chikungunya virus and host components: a possible mechanism for the arthritic manifestations. PLoS Negl Trop Dis 11:e0005238

Rezza G (2015) Do we need a vaccine against chikungunya? Pathog Glob Health 109(4):170-173. https://doi.org/10.1179/2047773215Y. 0000000017

Rezza G (2018) Chikungunya is back in Italy: 2007-2017. J Travel Med 25(1). https://doi.org/10.1093/jtm/tay004

Rezza G, Weaver SC (2019) Chikungunya as a paradigm for emerging viral diseases: evaluating disease impact and hurdles to vaccine development. PLoS Negl Trop Dis 13(1):e0006919. https://doi.org/10. 1371/journal.pntd.0006919

Robinson MC (1955) An epidemic of virus disease in Southern Province, Tanganyika territory, in 1952-53. I Clinical features. Trans R Soc Trop Med Hyg 49(1):28-32. https://doi.org/10.1016/0035-9203(55) 90080-8

Robinson WE Jr, Montefiori DC, Mitchell WM (1988) Antibodydependent enhancement of human immunodeficiency virus type 1 infection. Lancet 1(8589):790-794. https://doi.org/10.1016/s01406736(88)91657-1

Rosen L, Shroyer DA, Tesh RB, Freier JE, Lien JC (1983) Transovarial transmission of dengue viruses by mosquitoes: Aedes albopictus and Aedes aegypti. Am J Trop Med Hyg 32(5):1108-1119. https:// doi.org/10.4269/ajtmh.1983.32.1108

Ross RW (1956) The Newala epidemic. III. The virus: isolation, pathogenic properties and relationship to the epidemic. J Hyg (Lond) 54(2):177-191. https://doi.org/10.1017/s0022172400044442

Rosso F, Rodriguez S, Cedano JA, Mora BL, Moncada PA, Velez JD (2018) Chikungunya in solid organ transplant recipients, a case series and literature review. Transpl Infect Dis 20(6):e12978. https:// doi.org/10.1111/tid.12978

Rothan HA, Bidokhti MRM, Byrareddy SN (2018) Current concerns and perspectives on Zika virus co-infection with arboviruses and HIV. J Autoimmun 89:11-20. https://doi.org/10.1016/j.jaut.2018.01.002

Runowska M, Majewski D, Niklas K, Puszczewicz M (2018) Chikungunya virus: a rheumatologist's perspective. Clin Exp Rheumatol 36(3):494-501

Sa PKO, Nunes MM, Leite IR, Campelo M, Leao CFR, Souza JR, Castellano LR, Fernandes AIV (2017) Chikungunya virus infection with severe neurologic manifestations: report of four fatal cases. Rev Soc Bras Med Trop 50:265-268

Safaeian M, Porras C, Pan Y, Kreimer A, Schiller JT, Gonzalez P, Lowy DR, Wacholder S, Schiffman M, Rodriguez AC, Herrero R, Kemp T, Shelton G, Quint W, van Doorn LJ, Hildesheim A, Pinto LA, Group CVT (2013) Durable antibody responses following one dose of the bivalent human papillomavirus L1 virus-like particle vaccine in the Costa Rica Vaccine Trial. Cancer Prev Res (Phila) 6(11): 1242-1250. https://doi.org/10.1158/1940-6207.CAPR-13-0203

Senanayake MP, Senanayake SM, Vidanage KK, Gunasena S, Lamabadusuriya SP (2009) Vertical transmission in chikungunya infection. Ceylon Med J 54:47-50

Schiller J, Chackerian B (2014) Why HIV virions have low numbers of envelope spikes: implications for vaccine development. PLoS Pathog 10(8):e1004254. https://doi.org/10.1371/journal.ppat. 1004254

Scott SSO, Braga-Neto P, Pereira LP, Nobrega PR, de Assis Aquino Gondim F, Sobreira-Neto MA, Schiavon CCM (2017) Immunoglobulin-responsive chikungunya encephalitis: two case reports. J Neuro-Oncol 23(4):625-631. https://doi.org/10.1007/ s13365-017-0535-y

Selvarajah S, Sexton NR, Kahle KM, Fong RH, Mattia KA, Gardner J, Lu K, Liss NM, Salvador B, Tucker DF, Barnes T, Mabila M, Zhou X, Rossini G, Rucker JB, Sanders DA, Suhrbier A, Sambri V,
Michault A, Muench MO, Doranz BJ, Simmons G (2013) A neutralizing monoclonal antibody targeting the acid-sensitive region in chikungunya virus E2 protects from disease. PLoS Negl Trop Dis 7(9):e2423. https://doi.org/10.1371/journal.pntd.0002423

Simon F, Javelle E, Cabie A, Bouquillard E, Troisgros O, Gentile G, Leparc-Goffart I, Hoen B, Gandjbakhch F, Rene-Corail P, Franco JM, Caumes E, Combe B, Poiraudeau S, Gane-Troplent F, Djossou F, Schaerverbeke T, Criquet-Hayot A, Carrere P, Malvy D, Gaillard $P$, Wendling D, Societe de pathologie infectieuse de langue $\mathrm{f}(2015)$ French guidelines for the management of chikungunya (acute and persistent presentations). November 2014. Med Mal Infect 45(7): 243-263. https://doi.org/10.1016/j.medmal.2015.05.007

Sitati E, McCandless EE, Klein RS, Diamond MS (2007) CD40-CD40 ligand interactions promote trafficking of $\mathrm{CD} 8+\mathrm{T}$ cells into the brain and protection against West Nile virus encephalitis. J Virol 81(18):9801-9811. https://doi.org/10.1128/JVI.00941-07

Smith SA, Silva LA, Fox JM, Flyak AI, Kose N, Sapparapu G, Khomandiak S, Ashbrook AW, Kahle KM, Fong RH, Swayne S, Doranz BJ, McGee CE, Heise MT, Pal P, Brien JD, Austin SK, Diamond MS, Dermody TS, Crowe JE Jr (2015) Isolation and characterization of broad and ultrapotent human monoclonal antibodies with therapeutic activity against chikungunya virus. Cell Host Microbe 18(1):86-95. https://doi.org/10.1016/j.chom.2015.06.009

Sparrow E, Friede M, Sheikh M, Torvaldsen S (2017) Therapeutic antibodies for infectious diseases. Bull World Health Organ 95(3):235237. https://doi.org/10.2471/BLT.16.178061

Srinivasan SGM, Maity S, Varadarajan R (2016) Broadly neutralizing antibodies for therapy of viral infections. Antibody Technol J 6:1-15

Stec DS, Waddell A, Schmaljohn CS, Cole GA, Schmaljohn AL (1986) Antibody-selected variation and reversion in Sindbis virus neutralization epitopes. J Virol 57(3):715-720

Suhrbier A, Jaffar-Bandjee MC, Gasque P (2012) Arthritogenic alphaviruses-an overview. Nat Rev Rheumatol 8(7):420-429. https://doi.org/10.1038/nrrheum.2012.64

Sun S, Xiang Y, Akahata W, Holdaway H, Pal P, Zhang X, Diamond MS, Nabel GJ, Rossmann MG (2013) Structural analyses at pseudo atomic resolution of chikungunya virus and antibodies show mechanisms of neutralization. Elife 2:e0435. https://doi.org/10.7554/ eLife.00435

Sun H, Chen Q, Lai H (2017) Development of antibody therapeutics against flaviviruses. Int J Mol Sci 19(1). https://doi.org/10.3390/ ijms19010054

Takada A, Kawaoka Y (2003) Antibody-dependent enhancement of viral infection: molecular mechanisms and in vivo implications. Rev Med Virol 13(6):387-398. https://doi.org/10.1002/rmv.405

Tan CH, Wong PS, Li MZ, Tan SY, Lee TK, Pang SC, Lam-Phua SG, Maideen N, Png AB, Koou SY, Lu D, Ng LC (2011) Entomological investigation and control of a chikungunya cluster in Singapore. Vector Borne Zoonotic Dis 11(4):383-390. https://doi.org/10. 1089/vbz.2010.0022

Tanabe ISB, Tanabe ELL, Santos EC, Martins WV, Araujo I, Cavalcante MCA, Lima ARV, Camara NOS, Anderson L, Yunusov D, Bassi EJ (2018) Cellular and molecular immune response to chikungunya virus infection. Front Cell Infect Microbiol 8:345. https://doi.org/ 10.3389/fcimb.2018.00345

Tang BL (2012) The cell biology of Chikungunya virus infection. Cell Microbiol 14:1354-1363

Tharmarajah K, Mahalingam S, Zaid A (2017) Chikungunya: vaccines and therapeutics. F1000Res 6:2114. https://doi.org/10.12688/ f1000research.12461.1

Tsetsarkin KA, Vanlandingham DL, McGee CE, Higgs S (2007) A single mutation in chikungunya virus affects vector specificity and epidemic potential. PLoS Pathog 3(12):e201. https://doi.org/10.1371/ journal.ppat.0030201

Vijayakumar KP, Nair Anish TS, George B, Lawrence T, Muthukkutty SC, Ramachandran R (2011) Clinical profile of chikungunya 
patients during the epidemic of 2007 in Kerala, India. J Global Infect Dis 3(3):221-226. https://doi.org/10.4103/0974-777X.83526

Volk SM, Chen R, Tsetsarkin KA, Adams AP, Garcia TI, Sall AA, Nasar F, Schuh AJ, Holmes EC, Higgs S, Maharaj PD, Brault AC, Weaver SC (2010) Genome-scale phylogenetic analyses of chikungunya virus reveal independent emergences of recent epidemics and various evolutionary rates. J Virol 84(13):6497-6504. https://doi.org/10. 1128/JVI.01603-09

Vollmers HP, Brandlein S (2005) The "early birds": natural IgM antibodies and immune surveillance. Histol Histopathol 20(3):927-937. https://doi.org/10.14670/HH-20.927

Vrati S, Fernon CA, Dalgarno L, Weir RC (1988) Location of a major antigenic site involved in Ross River virus neutralization. Virology 162(2):346-353

Warter L, Lee CY, Thiagarajan R, Grandadam M, Lebecque S, Lin RT, Bertin-Maghit S, Ng LF, Abastado JP, Despres P, Wang CI, Nardin A (2011) Chikungunya virus envelope-specific human monoclonal antibodies with broad neutralization potency. J Immunol 186(5): 3258-3264. https://doi.org/10.4049/jimmunol.1003139

Weaver SC, Osorio JE, Livengood JA, Chen R, Stinchcomb DT (2012) Chikungunya virus and prospects for a vaccine. Expert Rev Vaccines 11(9):1087-1101. https://doi.org/10.1586/erv.12.84

Weber C, Berberich E, von Rhein C, Henss L, Hildt E, Schnierle BS (2017) Identification of functional determinants in the chikungunya virus E2 protein. PLoS Negl Trop Dis 11(1):e0005318. https://doi. org/10.1371/journal.pntd.0005318

Wong HV, Vythilingam I, Sulaiman WY, Lulla A, Merits A, Chan YF, Sam IC (2016) Detection of persistent chikungunya virus RNA but not infectious virus in experimental vertical transmission in Aedes aegypti from Malaysia. Am J Trop Med Hyg 94(1):182-186. https:// doi.org/10.4269/ajtmh.15-0318

Yap G, Pok KY, Lai YL, Hapuarachchi HC, Chow A, Leo YS, Tan LK, Ng LC (2010) Evaluation of chikungunya diagnostic assays: differences in sensitivity of serology assays in two independent outbreaks. PLoS Negl Trop Dis 4(7):e753. https://doi.org/10.1371/journal. pntd.0000753

Young AR, Locke MC, Cook LE, Hiller BE, Zhang R, Hedberg ML, Monte KJ, Veis DJ, Diamond MS, Lenschow DJ (2019) Dermal and muscle fibroblasts and skeletal myofibers survive chikungunya virus infection and harbor persistent RNA. PLoS Pathog 15: e1007993

Ziegler SA, Lu L, da Rosa AP, Xiao SY, Tesh RB (2008) An animal model for studying the pathogenesis of chikungunya virus infection. Am J Trop Med Hyg 79(1):133-139

Publisher's note Springer Nature remains neutral with regard to jurisdictional claims in published maps and institutional affiliations. 